\title{
ENVIRONMENTÁLNA HISTÓRIA HORNÉHO TISOVNÍKA. TRANSFORMÁCIA VYUŽITIA ZEME OD NESKORÉHO STREDOVEKU CEZ NOVOVEKÚ EXPANZIU PRIEMYSLU AŽ PO SÚČASNÉ OPÚŠŤANIE VIDIEKA
}

\author{
MARTINA SLÁMOVÁ - PAVEL HRONČEK
}

\begin{abstract}
Abstrakt: Hodnota pol'nohospodárskej krajiny katastrálneho územia Horného Tisovnika nespočiva v úrodnej pôde, ale v rozsiahlom systéme pol’nohospodárskych terás pretrvávajúcich vúzemi najmenej 250-300 rokov. Terasy reprezentujú výnimočné kultúrne a historické dedičstvo. Hlavným ciel'om príspevku je objasnenie vzniku a vývoja terás s využitím metodických prístupov environmentálnej histórie. Pri výskume sme analyzovali prírodné podmienky, historické a súčasné využitie zeme a produkčné vlastnosti pol'nohospodárskej pôdy. Pomocou historických prameňov a terénneho prieskumu sme určili typy terás a základné parametre. Na základe syntéz a interpretácii environmentálnych a historických dát sme vysvetlili dôvody ich vzniku a postupného vývoja od polovice 16. storočia až po súčasnost', ako aj príciny ich nerovnomerného geografického rozširenia v katastrálnom území. Výsledky dokazujú potrebu rešpektovania lokálneho historického polnohospodárskeho vedomostného systému pre budúce návrhy optimalizácie využitia územia.
\end{abstract}

Kl’účové slová: vývoj krajiny - environmentálna história - využitie zeme - čas a priestor - historické terasy - kultúrna a historická hodnota.

Environmental History of Horný Tisovnik: Transformations of land uses from the late Middle Ages, through industrial expansion during the Modern Age to the current abandonment of the countryside

Abstract: The value of the agricultural landscape of the cadastral area of Horny Tisovnik does not correspond to fertile soil, but it is expressed by the extensive system of agricultural terraces which have persisted in the area for at least 250 to 300 years. The terraces represent an exceptional cultural and historical heritage. The aim of this paper is to clarify the origin and evolution of the terraces using methodological approaches of environmental history. In the research, we analysed their natural conditions, historical and current land uses and the production properties of farmland. Using historical sources and the field survey, we identified types of terraces and their basic parameters. Based on data syntheses and interpretations of environmental and historical factors, the reasons for their origin and gradual development from the mid-16th century to the present time were explained, as well as the reasons for their uneven geographical distribution in the cadastral territory. The results demonstrated the need to respect a local historical agricultural knowledge system for the optimizing of the design of the future land use.

Key words: landscape genesis - environmental history - land use - time and space - historical terraces - cultural and historical value.

\section{Úvod}

\section{Význam poznatkov z environmentálnej histórie vo výskume kultúrnej krajiny}

Historici najčastejšie interpretujú históriu z archívnych prameňov, ktoré verifikujú a dopĺn̆ajú terénnym prieskumom. Pri rekonštrukcii zaujímavých aspektov minulých kultúrnych a socio-ekonomických vzt’ahov spoločnosti a jej životného prostredia (krajiny) takýto prístup limituje používaný metodický aparát, ktorý je zameraný skôr na zhromažd’ovanie informácií a ich kritické hodnotenie, ako na hl'adanie súvislostí, vzt’ahov a interakcií. Prvé práce k environmentálnym dejinám v zahraničí publikovali Worster 1988; Simmons 1998, 335-361; McNeill 
2003; Hughes 2006; Myllyntaus ed. 2011 a v posledných rokoch aj viacerí autori v Čechách a na Slovensku (Jeleček 2010; Holec 2014; Hronček 2014; 2014a, 19-21; 2017). Environmentálne dejiny môžeme charakterizovat' ako transdisciplinárny komplexný systémový výskum interakcií a väzieb organizmov a populácií (vrátane l'udskej spoločnosti, človeka a jeho kultúry, myslenia, spôsobu života a techniky) v ich životnom prostredí a v časopriestore (historická a súčasná krajina; Hronček 2014). V posledných rokoch sa začala rozvíjat' environmentálna história využívajúca exaktné metódy na dokazovanie tvrdení o ekologických a environmentálnych vzt'ahoch l'udskej spoločnosti a krajiny v minulosti (Hoffman 2014; Lewis 2014, 207-227; Slámová et al. 2017). Aj pre tento príspevok je preto výzvou exaktná interpretácia environmentálnych a historických vzt’ahov l’udskej spoločnosti v historickom chotári a v súčasnom katastrálnom území Horného Tisovníka, ktoré je na prvý pohl’ad zaujímavé prítomnostou rozsiahleho systému pol'nohospodárskych terás pokrývajúcich svahy údolia potoka Tisovník, i napriek tomu, že pre intenzívnu pol'nohospodársku činnost' sú tu menej vhodné prírodné podmienky. Systém pol’nohospodárskych terás odráža špecifiká historického využívania krajiny, a to najneskôr od neskorého stredoveku.

\section{Stručný historický vývoj a premeny tradične využívanej pol'nohospodárskej krajiny s terasa- mi na Slovensku}

Pol'nohospodárske terasy začali vznikat' na Slovensku počas valašskej kolonizácie podhorských a horských oblastí medzi 14.-16. storočím (Stankoviansky 2003, 91; napr. pahorkatinové časti kotlín či predhoria pohorí) a neskôr v 17.-19. storočí počas dosídlovania horských oblastí, ktoré boli menej vhodné pre pol’nohospodárstvo kvôli málo úrodným pôdam, drsným klimatickým a terénnym podmienkam (Špulerová et al. 2014, 135), ako napríklad v regiónoch Orava či Kysuce. Na konci 19. storočia bola krajina rôznorodá, typická bola malobloková orná pôda (Hanušin 2003, 371), mala vysokú biodiverzitu, rôznorodost' reliéfnych foriem a boli v nej prítomné rôzne drobné l'udové stavby (vínne pivnice, prícestné kríže, hospodárske budovy a iné), ktoré odrážali vo svojej architektúre zvyky a tradície regiónu, t’ažký život gazdov, ale i vieru (Špulerová et al. 2014, 143). Terasy na strmých svahoch mali protierózny účinok (Hanušin 2003, 373). Neskôr, počas komunistického režimu sa súkromné vlastníctvo pôdy značne zredukovalo a tradične využívané kultúrne krajiny sa stali vzácne (Lieskovský et al. 2015, 76-77). Následná intenzifikácia pol'nohospodárstva v roku 1970 spôsobila ešte rozsiahlejšiu deštrukciu tradičných foriem pol’nohospodárstva (Bezák-Halada 2010, 195). V súčasnosti sa tradične využívané terasy zachovali len v ekonomicky marginálnych pol'nohospodárskych oblastiach na Slovensku, a aj to len lokálne (Špulerová-Petrovič 2011, 160). Krajinné mozaiky („orná pôda - lúka - pastviny“) krajinného archetypu s tradičným pol'nohospodárstvom pretrvávajú na Slovensku prevažne v okrajových pol’nohospodárskych podhorských a horských oblastiach (Hreško et al. 2010, 166), čo je aj prípad Horného Tisovníka. Tradičné využitie zeme v okolí fariem, ktoré sa zachovalo v podobe historických krajinných štruktúr, sa v súčasnom vzhl’ade krajiny prejavuje ako vizuálny súlad farmy a krajiny (Hendriks et al. 2000, 163).

\section{Charakteristika územia}

\section{Poloha katastrálneho územia Horný Tisovník a charakteristika prírodných pomerov}

Katastrálne územie Horného Tisovníka leží na strednom Slovensku a nachádza sa v dvoch pohoriach západných Karpát, a to Ostrôžky (východne od potoka Tisovník) a Krupinská planina (západne od potoka Tisovník). Potok Tisovník, prameniaci pod vrchom Javorie (1 $044 \mathrm{~m}$ n.m.) a pretekajúci severojužným smerom, rozdel'uje katastrálne územie medzi tieto dve pohoria. Celé územie leží v geologickej jednotke stredoslovenských neovulkanitov, kde prevažujú andezitové a pyroklastické horniny. Tufy a tufity sa vyskytujú lokálne. Prevažujú mierne úrodné, mierne hlboké a hlboké modálne a neutrálne kyslé kambizeme a kultizeme (Miklós-Hrnčiarová edd. 2002, 107). Nadmorská výška stúpa smerom z juhu na sever, v smere toku Tisovníka, to znamená, že na južnej hranici katastra pri toku Tisovník je nadmorská výška $350 \mathrm{~m} \mathrm{n.m.,} \mathrm{okolité}$ 
vrchy dosahujú nadmorskú výšku od 500 do $700 \mathrm{~m}$ n.m. a z jednotiek potenciálnej prirodzenej vegetácie sa tu vyskytujú karpatské dubovo-hrabové lesy. Na severnej hranici katastra pri vodnom toku Tisovníka je nadmorská výška $666 \mathrm{~m}$ n. m., okolité vrchy dosahujú výšky okolo 650 $800 \mathrm{~m}$ n.m. a vyskytujú sa tu bukové a jedl'ovo-bukové lesy. V celom území prevažuje vrchovinný typ reliéfu a centrálnu, prevažnú čast' územia pokrýva jednotka potenciálne prirodzenej vegetácie podhorských bukových lesov. Severná čast' katastrálneho územia Horného Tisovníka podl'a Atlasu krajiny Slovenskej republiky (Miklós-Hrnčiarová edd. 2002, 139) korešponduje s rozptýleným osídlením (laznícke osídlenie) a súvisiacimi historickými krajinnými štruktúrami (malo-bloková orná pôda, medze a pol'nohospodárske terasy; obr. 1). Avšak rozsiahly systém historických pol'nohospodárskych terás sa vyskytuje v celom riešenom území a vytvára jeho osobitý historicko-kultúrny ráz (obr. 1).

Súčasné demografické indikátory poukazujú na vyl’udňovanie územia. V obci Horný Tisovník bolo v roku 2012 registrovaných iba 210 obyvatelov, čo je menej ako v roku 2001 (273; Štatistický úrad SR 2017). Očakáva sa, že populácia bude mat' pravdepodobne aj v budúcnosti klesajúci trend; prirodzený prírastok obyvatel'stva za rok 2014 predstavoval rozmedzie od -2 do 0 obyvatelov. V katastrálnom území je malý podiel ornej pôdy $\left(1,6 \mathrm{~km}^{2}\right)$, prevažujú trvalé trávne porasty $\left(10,1 \mathrm{~km}^{2}\right.$; Štatistický úrad SR 2017), čo svedčí o extenzívnom pol'nohospodárskom využití. Celkovo pol'nohospodárska krajina prirodzene zarastá drevinami a miestami sa mení na les (obr. 1 - fotografia a ortofotosnímka vpravo hore).

Nepriaznivá geografická poloha a komplikovaný prístup k dopravným a obchodným centrám v minulosti zarad’ovali celý severozápadný Novohrad, kde Horný Tisovník historicky patril, medzi oblasti, kde modernizačné prvky a nové myšlienky prenikali výrazne neskôr (Aláč $2015,13)$. Na periférnost' územia - doliny a absenciu významnejšieho osídlenia až do 16. storočia nás upozorňuje aj absencia cestnej siete, ktorú v Poiplí detailne zrekonštruoval vo svojej práci P. Ivanič (2011). Vd’aka izolácii si región aj do súčasnosti zachoval mnohé inde už zaniknuté architektonické prvky a špecifickú atmosféru (Aláč 2015, 13). Práve historické terasy a lokálne zachovaná l'udová architektúra (napr. známe Hornotisovnícke náhrobné kamene) vytvárajú potenciál pre rozvoj turizmu, a to hlavne agroturizmu, ktorý by mohol napomôct' pri revitalizácii v súčasnosti zanedbanej pol’nohospodárskej krajiny.

\section{Osídlenie územia do obdobia neskorého stredoveku}

Pralesom porastená krajina v kombinácii so strmými svahmi a skalnatým až bralným reliéfom bola človekom využitel'ná len vel'mi obmedzene. V geografickom priestore horného toku Tisovníka môžeme predpokladat' prvé kontakty človeka s krajinou, ako aj jej neskoršieho hlavného transformačného činitel'a už v strednej dobe bronzovej (1500-1200 pred Kr.). Archeologickými nálezmi je doložená prítomnost' l'udu pilinskej kultúry, ktorý si svoje výšinné hradisko vybudoval južne od kóty Bralo (Eisner 1933, 186; Balasa 1960, 16). Z Brala sú zmienené aj zlomky keramiky z neskorej doby laténskej. Na jeho východných aj západných svahoch sú čitatel'né terasovité úpravy terénu. Na západnej strane je pôvodný fortifikačný múr, vybudovaný z nasucho ukladaných kameňov. Datovanie objektov je otázne, ale vzhl'adom na nález novovekého črepu zo západného svahu je pravdepodobný skôr chronologicky mladší ako praveký pôvod (Beljak et al. 2015, 30).

Od začiatku nášho letopočtu sa na našom území postupne stabilizovalo podnebie a následne prirodzeným vývojom vymodelovaný georeliéf krajiny bol postupne osídlený pôvodnou pralesovitou vegetáciou v období mladšieho subatlantiku, t. j. po roku 500 po Kristovi (Krippel 1986, 210-215). Výnimkou nebola ani horná čast’ doliny Tisovníka, kde rástol rozsiahly primárny prales. Okolo vodných tokov bol tvorený komplexmi hustých lužných lesov. V južnej časti katastrálneho územia rástli dubové a dubovo-hrabové pralesy a tieto vytvárali t’ažko preniknutel'ný porast. Na strmých svahoch a bralách bol hustý prales s najväčšou pravdepodobnostou prerušovaný teplomilnými xerotermnými lesostepami s riedkymi porastmi dubov (hlavne južné slnečné svahy). Okrem krovinného porastu tam dominoval predovšetkým dub cerový (Quercus ceris L.). Dubové porasty (Quercus sp.) obohacoval hrab (Carpinus betulus L.). V strednej časti 


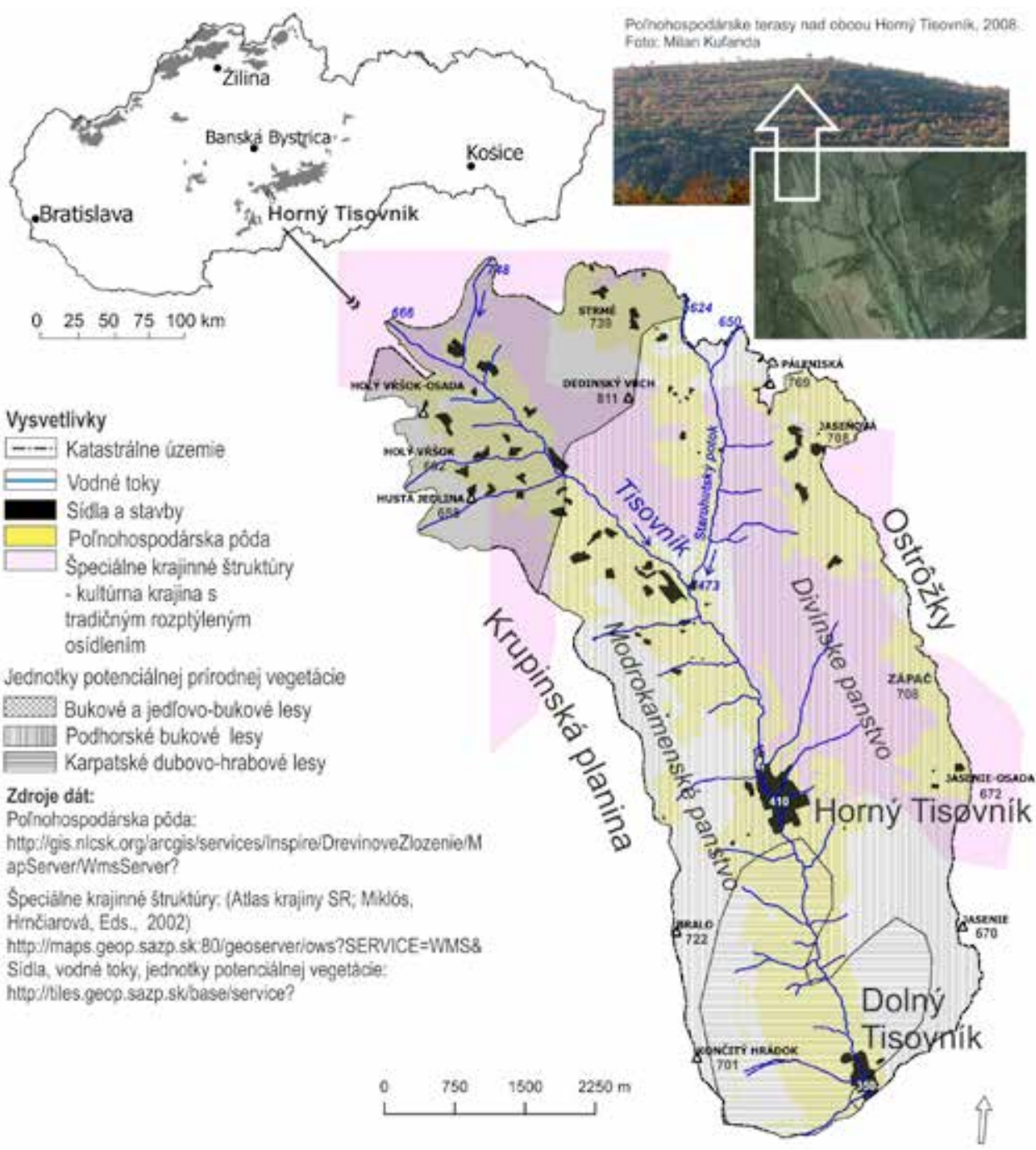

Obr. 1. Geomorfologické jednotky a nadmorské výšky (m n.m.), historické panstvá, súčasné pol’nohospodárske využitie zeme (2018), tradičná pol'nohospodárska krajina s roztrateným osídlením (Miklós-Hrnčiarová edd. 2002), historicky dokumentované názvy lazníckeho osídlenia (z mapy z II. vojenského mapovania 1810-1869) s nadmorskou výškou a vrchy s nadmorskou výškou.

Abb. 1. Geomorphologische Einheiten und Höhenangaben ( $m$ ü. NHN), historische Herrschaften, gegenwärtige landwirtschaftliche Nutzung des Bodens (2018), traditionelle Agrarlandschaft mit Streubesiedelung (Miklós-Hrnčiarová edd. 2002), historisch dokumentierte Namen der Einsiedeleien (aus der Karte der zweiten militärischen Kartierung 1810-1869) mit Höhenangaben ( $m$ ü. NHN) und Berge mit Höhenangaben ( $m$ ü. NHN).

katastrálneho územia a v severnej, v závere doliny Tisovníka rástli prevažne bukové (Fagus sylvatica L.) pralesy (Michalko et al. 1985, 165).

Primárny prales bol podl'a definície prof. Š. Korpel’a prales (v užšom zmysle slova) - človekom neovplyvnený pôvodný les, ktorý v danej oblasti podl’a druhového zloženia predstavoval posledný článok fylogenetického vývoja lesa. Jeho podstatná vývojová čast' ostávala trvalo v klimaxovom štádiu pri cyklicky sa opakujúcich zmenách generácií základných drevín dlhej životnosti (Korpel' 1989, 26). V stredoveku v týchto pralesoch rástli mohutné stromy s vysokými 
kmeňmi. Lesy mali bylinný porast, ale krovinová etáž bývala vel'mi riedka alebo úplne absentovala. Juvenilné jedince dominujúcich drevín po prirodzenom odumretí starých stromov zaujali uvol'nený priestor v hornej etáži pralesa. Na zemi odumierajúce aj niekol'ko metrov dlhé kmene stromov mali hrúbku často až do $2 \mathrm{~m}$, preto ich človek musel obchádzat' (Michalko et al. 1986, 165).

Napriek archeologicky doloženému vel'mi skorému kontaktu človeka s krajinou Horného Tisovníka môžeme predpokladat' existenciu pôvodných pralesov v tomto geografickom priestore až do stredoveku (Kavuljak 1942, 28-98). V 13. storočí, ked' sa formuje správa hradných na tomto území, bola dolina horného Tisovníka stále neosídlená (Alberty et al. 1989, 135-136). Do pralesovitého, takmer nezmeneného prírodného prostredia začínajú pravdepodobne v 14. storočí prichádzat' prví stredovekí osadníci (Alberty et al. 1989, 139), ktorí tu neskoršom období od polovice 16. storočia sformovali trvalé osídlenie. Osadníci získavali z pralesov stavebný materiál, výrobný materiál pre širokú škálu náradia a nástrojov dennej potreby či rôznych predmetov. Les bol tiež jediným zdrojom paliva a nenahraditel'ným zdrojom obživy. Poskytoval množstvo rastlinných zdrojov pre potravu, ako boli huby, lesné plody, byliny, koreniny či med a rôzne št’avy. Využíval sa aj na lov živočíchov, či už na mäso, ale aj pre kožušiny a loj, ku ktorému neodmyslitel'ne patrilo aj pytliactvo. Lesný priestor vytvoril aj podmienky na rozvoj nespočetného množstva lesných remesiel, ktoré sa stali základom hospodárstva a obživy v neskorom stredoveku a novoveku. Prvotným zamestnaním osadníkov bolo drevorubačstvo zamerané na t’ažbu stavebného a palivového dreva. Popri drevorubačoch sa vyvinuli aj d’alšie lesné remeslá, a to predovšetkým uhliari a v menšej miere dechtári, smoliari či draslári. Rúbaniská na svahoch sa klčovali a kosili, často sa orali a sialo sa na nich obilie. V lesoch sa pásli kozy a ovce či kravy a hrabalo sa lístie ako stelivo pre hospodárske zvieratá. Na bukviciach sa pásli svine aj bravy. Vnímanie lesa vtedajším stredovekým človekom bolo rôzne. Môžeme predpokladat', že človek, ak chcel prežit', musel les vnímat' kladne, ale s rešpektom a na základe svojich skúseností ho využívat' vo svoj prospech. Je nesporné, že hlboké a človekom nedotknuté pralesy, porastajúce úzke hlboké doliny, často so skalným reliéfom, boli pre bežných obyvatel'ov často nebezpečné a poskytovali úkryty rôznym živlom, či už tulákom, vojenským zbehom, ale aj zbojníkom (Hronček 2015, 91-115).

Hranice hradných panstiev prebiehajúce po toku Tisovníka sa sformovali v druhej polovici 13. storočia v zalesnenej oblasti (Alberty et al. 1989, 139). Potok Tisovníka tvoril historickú hranicu panstiev (obr. 1). Štatisticky významne väčšie množstvo terás sa našlo na panstve Modrý Kameň, ktoré kládlo dôraz na rastlinnú výrobu, v porovnaní s Divínskym panstvom, ktoré v minulosti kládlo dôraz na priemyselnú výrobu a v ktorom pol’nohospodárska činnost' bola spojená hlavne s pasením a chovom dobytka. Rozdielne historické hospodárske zázemie oboch panstiev sa prejavuje aj v súčasnom využití zeme. Kým západná strana doliny Tisovníka si udržiava pol'nohospodársky charakter, východná strana je pokrytá prevažne lesmi (Slámová et al. 2017, 36).

\section{Ciele práce}

Hlavným ciel’om článku je interpretácia environmentálnych dejín krajiny od počiatkov neskorostredovekého osídlenia doliny horného toku Tisovníka (súčasného katastrálneho územia obce Horný Tisovník) s dôrazom na vysvetlenie príčin vzniku a vývoja pol’nohospodárskych terás a ich geografického a priestorového rozšírenia v území. Analyzovali sme historicko-geografické pramene (písomný materiál i historické mapy), prírodné podmienky súvisiace so stúpajúcou nadmorskou výškou v smere z juhu na sever, využitie zeme a produkčný potenciál pol’nohospodárskej pôdy. Na základe interpretácie historických a environmentálnych faktorov a odvodených súvislostí vysvetl'ujeme dôvody vzniku relatívne hustej koncentrácie terás v skúmanom území, ktoré nie je vhodné na intenzívnu pol'nohospodársku činnost', ako aj následky (v podobe degradácie pôdy) vyplývajúce $\mathrm{z}$ intenzívnej pol’nohospodárskej činnosti v území v minulosti a absentujúceho alebo nedostatočného využívania pôdy na terasách v súčasnosti. 
V teréne sme overili výskyt rozdielnych typov terás. Dôvod, prečo je Horný Tisovník zaujímavý terasami, je ich rozsiahlost'. V katastrálnom území Horného Tisovníka je hustota terás $6,3 \mathrm{~km} / \mathrm{km}^{2}$ (Slámová et al. 2017). Pre porovnanie, v obdobnej karpatskej pol'nohospodárskej podhorskej oblasti v povodí Stary Rzeky v Pol'sku Swiechovicz (2002) zistil hustotu terás v rozmedzí od $0,8 \mathrm{~km} / \mathrm{km}^{2}$ do $1,0 \mathrm{~km} / \mathrm{km}^{2}$. V mediteránnych oblastiach je hustota terás bežne niekol'konásobne vyššia. Agnoletti et al. $(2015,13889)$ zdokumentovali hustotu terás až $400 \mathrm{~m} / \mathrm{ha}$ v regióne stredozemného Toskánska. Terasy sme analyzovali v širšom historicko-geografickom kontexte a na základe poznania environmentálnych dejín pol’nohospodárskej krajiny Horného Tisovníka sme navrhli optimalizáciu pol'nohospodárskeho využitia terás a pripravili sme námety pre rozvoj vidieckeho turizmu.

\section{Metodika}

Pracovný postup obsahuje tri základné časti spracovania údajov a dát:

- Analytická čast’ bola zameraná na historicko-terénny prieskum o využití zeme a výskyte terás $\mathrm{v}$ krajine $\mathrm{v}$ minulosti, ktorý bol prvým a najdôležitejším postupovým krokom. V prvom rade bola vykonaná analýza historických údajov; od 16. storočia s využitím písomných zdrojov a od obdobia novoveku, od 18. storočia s využitím historických máp. Terénny prieskum bol zameraný na určenie typov terás a ich klasifikáciu (s využitím dostupnej literatúry o terasách) a jeho výsledky sme podporili archívnymi materiálmi. V teréne boli terasy dokumentované a merané v tranzekte, ktorý sme si vytýčili v základnej mape 1:10 000 pod Končitým hrádkom (701 m n. m.), v lokalite Zakrovo (historický názov).

- Syntetická čast' bola zameraná na vyhodnotenie výskytu terás v území vzhl’adom na prírodné podmienky, využitie zeme a produkčný potenciál pol'nohospodárskej pôdy (kvalita pôdy). Jednotky potenciálnej vegetácie reprezentujú geo-klimatický gradient; to znamená, že v smere z juhu na sever rastie nadmorská výška v katastrálnom území a v závislosti na tejto premennej sa menia jednotky potenciálnej vegetácie. Množstvo zastúpenia terás $\mathrm{v}$ jednotlivých kategóriách súčasného využitia zeme sme zistovali preto, aby sme vedeli porovnat' ich súčasné a historické využitie, ktoré sme zistili z historických máp. Zmeny vo využívaní územia sme následne interpretovali $\mathrm{v}$ poslednom postupovom kroku. Vyhodnotenie zastúpenia terás $\mathrm{v}$ kategóriách produkčného potenciálu pol’nohospodárskej pôdy vypovedalo o kvalite pol’nohospodárskej pôdy a vhodnosti jej využitia formou ornej pôdy či trvalých trávnych porastov.

- Interpretačná čast' bola zameraná na vysvetlenie environmentálnych dejín pol’nohospodárskej krajiny s terasami a širších historicko-environmentálnych a geografických (priestorových) súvislostí ich vzniku, vývoja a očakávaných trendov budúceho využitia napríklad v agroturizme.

Geo-priestorové dáta boli spracované a vyhodnotené v prostredí geografických informačných systémov (GIS) QGIS 2.18 a v programe MS Excel ${ }^{\mathrm{TM}}$.

\section{Analýzy: historicko-geografický a terénny prieskum}

Historicko-geografický výskum bol zameraný na identifikáciu, štúdiu a kritickú analýzu historických prameňov, či už písomných archívnych prameňov, kartografických prác, ale aj literárnych zdrojov (Gerber 1974; Hroch et al. 1985; Eco 1997; Dvořák et al. 2014).

Archívny výskum v Štátnom archíve Banská Bystrica (v priebehu roku 2015) bol zameraný na získanie písomných materiálov a interpretáciu údajov z historických máp:

- Mikovínyho mapy Novohradskej stolice, ktorá vyšla tlačou v roku 1742 (Bel 1742);

- Mapy I. vojenského mapovania (1764-1787);

- Mapy II. vojenského mapovania (1810-1869; originál v mierke 1 : 28 800); 
Rastrový georeferencovaný obraz historických máp bol dostupný cez webové mapové služby (WMS; Geografický a kartografický ústav [GKÚ ], 2018) a tieto mapy sme využili vo výsledkoch práce. Pre zistenie využitia zeme v období pred scel'ovaním pozemkov počas komunistických reforiem sme použili online mapu (1952-1957; GKÚ, 2018). Historické mapy sme uplatnili aj pre identifikáciu typov terás, ktoré boli overené počas terénneho prieskumu a porovnané so súčasnou situáciou parciel (Úrad geodézie, kartografie a katastra Slovenskej republiky [ÚGKK SR], 2018) na modelovom území v lokalite Zakrovo.

Práca $\mathrm{v}$ teréne nám pomohla overit' známe informácie a priviedla nás $\mathrm{k}$ novým, doposial' nepoznaným historickým javom a súvislostiam. Pri terénnom výskume antropogénneho mikroreliéfu terás sme postupovali podla overených metodických postupov J. Demeka (1987) a J. Laciku (1999), prípadne v súlade s metodickými postupmi, ktoré rozpracoval pre výskum montánnej krajiny P. Hronček (2014b). Pri práci v teréne bol dôležitý aj metodický postup „oral history“ (Ritche 2003; Veselská 2008), ktorý je v našom geografickom priestore zatial' nedocenený a málo využívaný. I ked' sa v území nachádza málo miestnych obyvatel'ov, podarilo sa nám s niektorými nadviazat' rozhovor o terasách a nové informácie boli prínosom pre našu prácu.

\section{Identifikácia terás v teréne. Určenie typov a parametrov terás}

Terénny prieskum bol zameraný na určenie rozdielnych typov terás a bol vykonaný v rámci projektu IPA 13/2010 v roku 2010 (máj až júl) a v roku 2017 (marec) v rámci projektu ERASMUS+ 2016-1-SK01-KA202-022502. Ako uvádza Stankoviansky (2001, 106), najfrekventovanejšou formou, vytvorenou následkom orania po vrstevnici, je terasové pole. Terasy sme pomenovali na základe známych klasifikácií (Zapletal 1968; 1969; Ivan 1993; Lasanta et al. 2013). Terénnym prieskumom sme dokumentovali terasy a pri ich analýze sme vychádzali z metodiky, ktorú rozpracoval L. Zapletal $(1968 ; 1969)$ a Lasanta et al. (2013). Agrárne terasy sú antropogénne vytvorené stupne na svahoch s takmer vodorovnou plošinou a strmým svahom stupňa terasy (čelom). Ich líniový tvar smerujúci takmer po vrstevnici morfologicky výrazne mení pôvodný reliéf krajiny. Pre agrárne terasy je typické základné pravidlo, že ich dížka výrazne niekol'konásobne prevyšuje výšku stupňa. Pri reze v profile potom terasy nápadne pripomínajú schodisko. V prípade, že sklon svahu je premenlivý, vznikajú terasy rôznej výšky a šírky stupňa. Pri plytších svahoch vznikajú spravidla nižšie a širšie terasy a naopak, pri strmších svahoch sú ich stupne vyššie a plošiny užšie. Samozrejme, ich dížka závisí od dížky (po vrstevnici) upravovaného prirodzeného svahu. Terasy sprístupňujú pre pol’nohospodárske využitie aj také svahy, ktoré sú strmšie ako $12 \%$, a podla odporúčania metodiky Výskumného ústavu pôdoznalectva a ochrany pôdy (VÚPOP; 2011) sú najefektívnejším protieróznym opatrením. Terasy svojimi stupňami zmenšujú sklon svahov, znižujú energiu reliéfu a chránia polia proti výmol’ovej, ale aj plošnej erózii.

Na základe genetickej klasifikácie podl’a L. Zapletala (1968, 337-339; 1969, 93-97) rozoznávame dva základné druhy agrárnych terás: stavané a vznikajúce samovol'ne. Lasanta et al. $(2013,488)$ rozoznáva tri základne typy s množstvom subtypov. Najbežnejší typ terasovitého pol’a zahŕňa plochú oblast' vymedzenú v dolnej časti svahu vertikálnym stupňom. V najdokonalejšom, ale aj najdrahšom modeli je taký vertikálny stupeň vytvorený kamennou stenou. V iných typoch je terasový stupeň pokrytý kríkmi či súvislým bylinným porastom, alebo sú tu dokonca ovocné stromy, ktoré pomáhajú udržiavat' pôdu na strmom svahu terasového stupňa. Terasy majú niekedy aj mierny sklon a môžu byt' ohraničené bylinnou vegetáciou alebo múrikom, vyrobeným z kameňov odstránených z pol’a počas jeho kultivácie.

Pre manuálne meranie terás v teréne pod lokalitou Končitý hrádok (701 m n.m.) sme použili meracie pásmo (s dížkou $50 \mathrm{~m}$ ), nitkový dial'komer Walktax (podl'a údajov výrobcu s presnostou merania v rozmedzí od $\pm 0,2$ do $\pm 0,7 \%$ ), sklonomer Suunto (PM-5/1520; s presnostou $1^{\circ}$ ) a geodetickú latu, ktorá bola pomôckou pri meraní výšok. Výšky terás sme rozdelili do kategórií: nízke (do 0,5 m); stredne vysoké (do 1,5 m) a vysoké (nad 1,5 m). Meranie prebehlo v roku 2010 v rámci projektu IPA 13/2010. Profil terás vo svahu sme skonštruovali na základe nameraných parametrov a údajov z mapy v programoch MS Excel $^{\mathrm{TM}}$ a CorelDraw ${ }^{\mathrm{TM}}$. Súčastou terénneho 


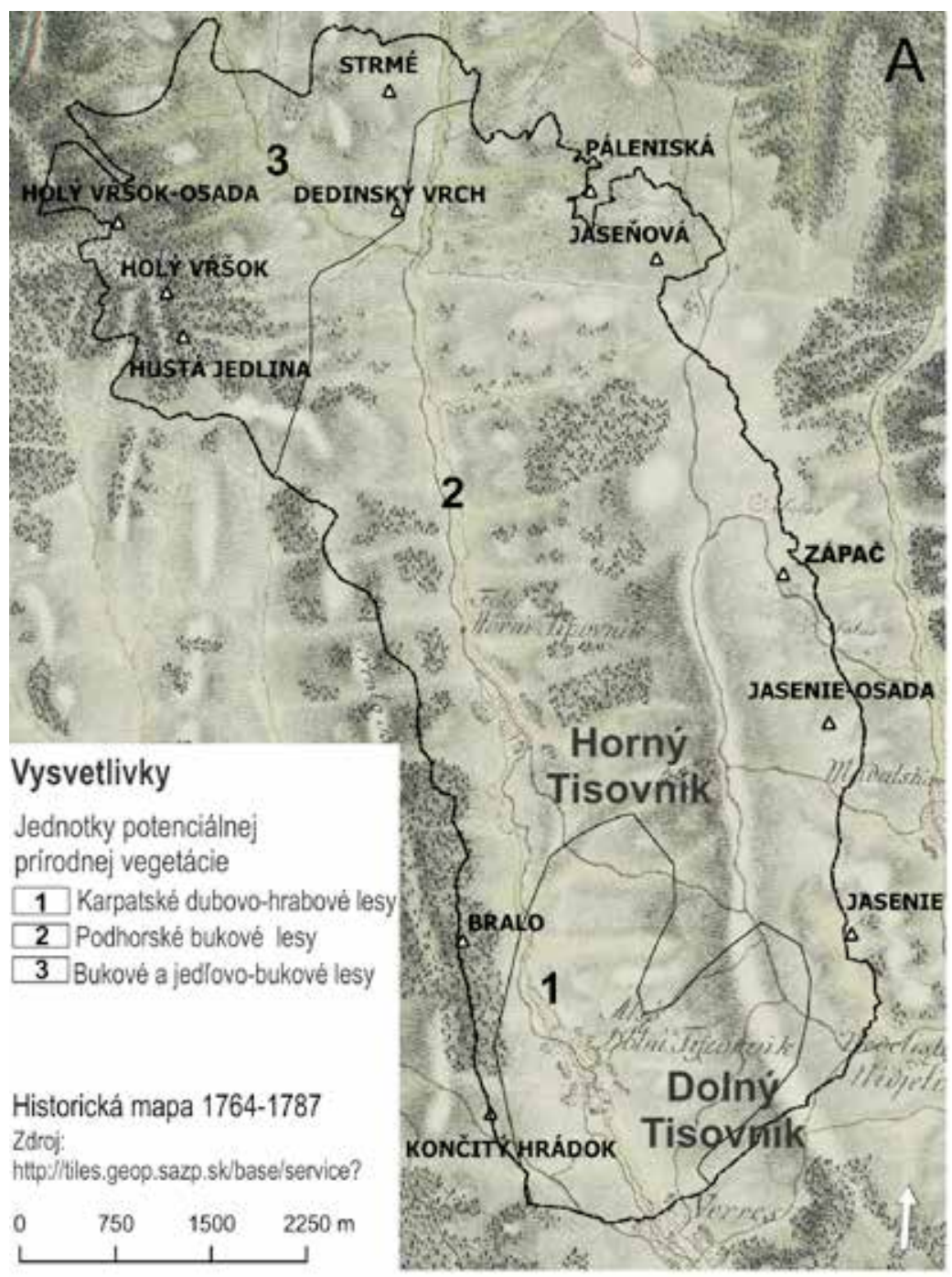

Obr. 2. Mapa I. vojenského mapovania (1764-1787) dokumentuje prevažujúce pol'nohospodárske využitie krajiny (A). Mapa II. vojenského mapovania (1810-1869) zobrazuje dolinu potoka Tisovník s terasami. Výrez z mapy z 50-tych rokov 20. storočia (1952-1957) zobrazuje odlesnenú najsevernejšiu čast’ katastra (B).

prieskumu bola aj fotodokumentácia rôznych druhov terás $\mathrm{v}$ lokalite, ktorá sa nachádza pod vrchom Končitý hrádok (701 m n.m.) a v lokalite pod vrchom Zápač $(737 \mathrm{~m} \mathrm{n.m.;} \mathrm{lokality} \mathrm{sú}$ označené rámikmi na historických mapách obr. 2:B).

Syntézy: Rozšírenie terás v katastri vzhl'adom na podmienky prírodného prostredia, využitie zeme, kvalitu pôdy a historické súvislosti osídlovania a využívania krajiny

Pol'nohospodárske terasy boli vektorizované zo základných máp 1 : 10000 Štátneho mapového diela Slovenskej republiky (ŠMD SR; GKÚ 2018). Množstvo terás sme hodnotili ako: dížku terás $[\mathrm{km}]$ a hustotu terás $\left[\mathrm{km} / \mathrm{km}^{2}\right]$. Výskyt a množstvo terás boli hodnotené v: 


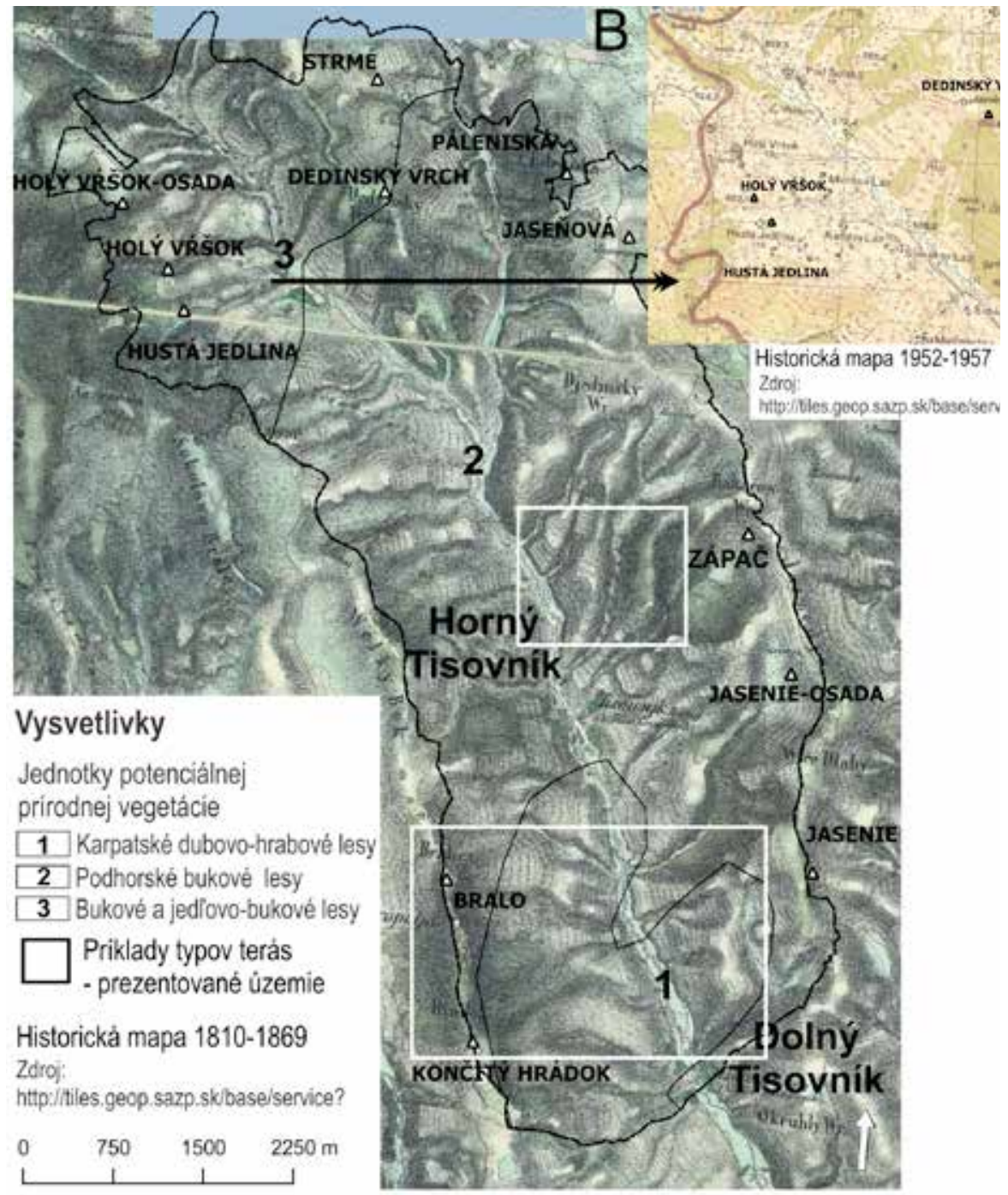

Abb. 2. Die Karte der ersten militärischen Kartierung (1764-1787) dokumentiert die überwiegende landwirtschaftliche Nutzung des Gebietes (A). Die Karte der zweiten militärischen Kartierung (1810-1869) gibt das Bachtal Tisovník mit Terrassen wieder. Der Kartenausschnitt aus den fünfziger Jahren des 20. Jahrhunderts (1952-1957) gibt den entwaldeten nördlichsten Teil des Katasters wieder (B).

- jednotkách potenciálnej prirodzenej vegetácie (Miklós-Hrnčiarová edd. 2002, 115): karpatské dubovo-hrabové lesy, podhorské bukové lesy a bukové a jedl'ovo-bukové lesy;

- kategóriách súčasného využitia zeme s lesohospodárskym využitím (Národné lesnícke centrum [NLC], 2018), kde jednotky priestorového rozdelenia lesa (JPRL) a ostatné lesné plochy (OLP) boli označené ako lesné pozemky; v sídlach a zastavaných plochách (GKÚ 2018) a na pol'nohospodárskej pôde.

- typologicko-produkčných kategóriách pol'nohospodárskej pôdy (VÚPOP 2011) reflektujúcich potenciálne využitie pôdy vzhl’adom na jej kvalitu vyplývajúcu z miestnych klimaticko-pôdno-ekologických pomerov: O6 - menej produkčné orné pôdy; O7 - málo produkčné orné pôdy; 
OT1 - stredne produkčné polia a produkčné trávne porasty; OT2 - menej produkčné polia a produkčné trávne porasty; OT3 - málo produkčné polia a produkčné trávne porasty; T1 - produkčné trvalé trávne porasty; T2 - menej produkčné trvalé trávne porasty; T3 - málo produkčné trvalé trávne porasty.

\section{Interpretácia environmentálno-historických súvislostí vývoja pol'nohospodárskych terás}

Porovnaním údajov o prírodných podmienkach vyplývajúcich z geo-klimatického gradientu, súčasného a historického využitia zeme v kontexte vývoja územia a neskorostredovekého správneho začlenenia do dvoch rozdielnych panstiev (s odlišnými spôsobmi hospodárenia), ako i produkčného potenciálu pol'nohospodárskych pôd na terasách sme zistili, či pol'nohospodárstvo fungovalo $\mathrm{v}$ súlade s prírodnými danost’ami územia alebo nie, a aké následky z toho vyplývali. Mnohé staré kultúrne krajiny majú vysokú kvalitu, ale systém manažmentu, v ktorých sa historická, kultúrna a prírodná hodnota vytvorila, už nie je v súčasnosti udržatel’ný (Vos-Meeks 1999 , 4). Preto je našou úlohou nájst' nové ekonomicky rentabilné spôsoby optimálneho využitia krajiny, ktoré vychádzajú z tradícií a súčasne podporujú rozvoj podnikania, hlavne formou turizmu.

\section{Výsledky}

Osídl'ovanie územia, vývoj využívania zeme a vznik pol’nohospodárskych terás od obdobia neskorého stredoveku do 50-tych rokov 20. storočia

Napriek archeologicky doloženému vel'mi skorému kontaktu človeka s krajinou Horného Tisovníka $\mathrm{v}$ dobe bronzovej môžeme predpokladat' pretrvávanie pôvodných pralesov $\mathrm{v}$ tomto geografickom priestore až do stredoveku (Kavuljak 1942, 28-98). V 13. storočí, ked' sa formuje správa hradných na tomto území, bola dolina horného Tisovníka stále neosídlená (Alberty et al. 1989, 135-136). Hranice hradných panstiev prebiehajúce po toku Tisovníka sa v druhej polovici 13. storočia sformovali v lesnej oblasti, ked’ západná čast' doliny patrila Modrokamenskému panstvu a východná čast' Divínskemu panstvu, a práve hradná správa a jej rozdielne hospodárske zameranie začali v nasledujúcich storočiach vplývat' na rozdielny vývoj využívania krajiny. Tieto hranice zostali nemenné až do 20. storočia.

Prví stredovekí osadníci tu sformovali trvalé osídlenie pravdepodobne v 14. storočí (Alberty et al. 1989, 139). Správa z roku 1548 už spomína obe sídla (Horný a Dolný Tisovník) ako majetok Balašovcov (Borovszky 1911). Vlastnili Modrokamenské panstvo, ktoré uprednostňovalo produkciu pol'nohospodárskych plodín a iných produktov. Išlo o západnú, pravú stranu doliny Tisovníka. Východnú čast' doliny od konca 17. storočia vlastnili Zichyzovci z Divína (Alberty et al. 1989, 208-211) a pôvodné lesné majetky zmenili na pol'nohospodársku pôdu, ale v pol'nohospodárstve prevažovalo pasienkarstvo a ekonomický význam mali hlavne remeslá a priemysel. Od prvopočiatkov v stredoveku sa jadrové obce formovali ako pol’nohospodárske sídla s tým, že od novoveku sa pri transformáciách krajiny výrazne uplatňovalo aj drevorubačstvo, uhliarstvo a nadväzujúce zamestnania, ako bolo piliarstvo, povozníctvo a sklárstvo.

$\mathrm{Na}$ odlesnenej pôde začali od 17. storočia vznikat' lazy. V období raného novoveku bola v severnej časti Novohradu intenzita tlaku človeka na krajinu už vel'ká a plošne sa prejavovalo odlesnenie na rozsiahlej ploche, na čo poukazuje Mikovínyho mapa (1742; Bel 1742), ktorá je prvým vedeckým obrazovým prameňom, a aj napriek nepresnosti kartografických metód vierohodne zobrazuje skúmaný geografický priestor. Vierohodnost' tohto prameňa potvrdzuje aj fakt, že S. Mikovíny sa narodil v ned'alekej obci Turíčky a môžeme ho pokladat' za vynikajúceho znalca vtedajšej krajiny severného Novohradu. Túto skutočnost' neskôr potvrdzuje aj mapa I. vojenského mapovania (1764-1787; obr. 2:A), ktorá zobrazuje lesy iba na severe územia (približne v nadmorskej výške 650-800 m n.m.). I ked' táto mapa vzhl'adom k svojej mierke a technike zobrazenia nezobrazuje terasy v pol'nohospodárskej krajine, S. Borovszky $(1911,14,41)$ a P. Martuliak $(2006,30)$ uvádzajú, že terasy sa rozprestierali po oboch stranách doliny Tisovníka. 
V prvej polovici 18. storočia mala krajina v severnej časti doliny Tisovníka stále charakter pralesov, v tomto prípade bukových a bukovo-jedl'ových. Tento stav je zrejmý aj zo súpisov v rokoch 1715 a 1720. Podl'a týchto súpisov bolo na začiatku 18. storočia v chotároch Horného a Dolného Tisovníka spolu cca 200 ha pol'nohospodárskej pôdy. Pol'nohospodárska pôda teda zaberala len necelých 7\% rozlohy severnej časti doliny Tisovníka (Magyar Nemzeti Levéltár 2010).

V druhej polovici 18. storočia nastáva intenzívnejšie odlesňovanie aj severnej časti doliny Tisovníka. Bukové lesy v strednej a severnej časti katastrálneho územia predstavovali významnú surovinu pre uhliarsky a drevospracujúci priemysel, preto boli vyrúbané hlavne v dôsledku hospodárskych činností rodu Balašovcov. Odlesňovanie severnej časti doliny Tisovníka urýchlila výstavba vodnej píly na sútoku Starohutského potoka s Tisovníkom pravdepodobne už začiatkom novoveku (Martuliak 2006, 46). K píle pribudla v 17. storočí aj skláreň Devínska Huta, v súčasnosti obec Stará Huta, ktorá pracovala na miestnej surovinovej základni dreva, drevného uhlia a kameňa. V sklárni pracovalo až 50 zamestnancov (Alberty et al. 1989, 223). Drevo tu bolo priamo popílené, prípadne odvezené povozníkmi z oboch Tisovníkov do celého Uhorska. Vel'ká čast' dreva bola na mieste vypálená na drevné uhlie (Alberty et al. 1989). V priebehu 19. storočia pribudli d’alšie tri sklárne. Podl'a mapy II. vojenského mapovania (1810-1869) v krajine ostávali zachované malé plochy lesa v dolinkách, výmol’och alebo stržiach ústiacich do potoka Tisovník, kde spevňovali strmé svahy a plnili protieróznu funkciu (obr. 2:B).

Rozmanitá a rastúca priemyselná činnost' spôsobila zintenzívnenie pol’nohospodárskej činnosti v území, ktoré vrcholilo na prelome 19.-20. storočia a začiatkom 20. storočia. Okrem drevorubačstva, respektíve lesných remesiel, sa stáva hlavným odlesňovacím faktorom aj pol'nohospodárstvo, a to aj v najsevernejších častiach doliny. S. Borovszky $(1911,14,41)$ a P. Martuliak $(2006,46)$ uvádzajú, že v severnej časti vzniklo v 18. storočí niekol'ko desiatok lazov a v ich názvoch sa uplatnilo meno zakladatel'a, alebo $\mathrm{v}$ mnohých prípadoch dostali pomenovanie aj podl'a rôznych špecifík krajiny. Tieto pomenovania sú podrobne uvedené v mape II. vojenského mapovania (1810-1869), napríklad: Medzi vrške, Hustá jedlina, Holý vršok, Lešná, Zápač, Jasenja, Jasenová či Strmô (obr. 2:B a výrez vpravo hore je z mapy z 50-tych rokov 20. storočia). Rozsiahle odlesnenie krajiny horného toku Tisovníka v druhej polovici 18. storočia potvrdzuje aj mapa I. vojenského mapovania z roku 1782.

\section{Genéza a charakteristika typov terás a parametre terasových polí z historických katastrálnych máp a terénneho merania}

Terasy začali vznikat' pri pol’nohospodárskej činnosti spontánne približne od obdobia neskorého stredoveku, najmä počas lazníckej kolonizácie, kedy sa začali pol’nohospodársky využívat' aj strmé svahy Krupinskej planiny a Ostrôžok. Počas orby polí na svahoch sa medze vedúce približne po vrstevnici stávajú postupným odorávaním hranou terasy. Terasy sa stali jedinou možnost’ou, ako efektívne obrábat' strmé polia na svahoch. Samovol'ne vytvorené terasy vznikali za neporovnatel'ne dlhšie obdobie (často aj storočia) než stavané. Neskôr začal človek postupne v menšom počte svahy terasovat' aj úmyselne. Tieto terasy vznikali priamou činnost'ou človeka a za vel'mi krátke obdobie. Avšak oba typy terás mali obdobné využitie. Rozdielnost' genézy ich vzniku závisela hlavne od sklonu prirodzeného terénu a naliehavosti kultivácie pôdy formou orania a samozrejme aj od prítomnosti prírodného materiálu - kameňa nevyhnutného na výstavbu terás. Kamenné terasy sa stavali tam, kde bol dostatok kameňa, a kde vznikla ekonomická potreba. Tam, kde bol nedostatok kameňa, sa čelá kultivačných terás postupne spevňovali koreňovým systémom vysadených drevín, často ovocných stromov, a takto sa zmierňovali následky erózie.

V skúmanom území sme identifikovali oba druhy terás. Samovol’ne vytvorené terasy vznikli spontánne pri vrstevnicovom obrábaní pôdy (obr. 3:A). Na niektorých svahoch boli terasy stavané z kameňa ako suché múriky (obr. 3:B). Mnohé historické terasy sú už v súčasnosti zarastené sukcesným náletom drevín (obr. 3:C), a to bez ohladu na to, či boli stavané, alebo vznikli spontánne. Na niektorých terasách sme v teréne našli rozkonárené jedince solitérnych drevín, ako je aj dokumentovaný hrab (Carpinus betulus L.) na fotke (obr. 3:C). Pestované dreviny na 

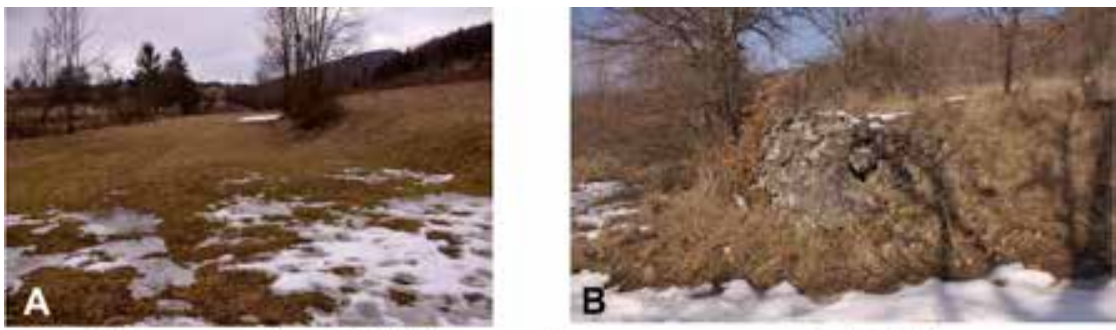

A - terasy vzniknuté kultiváciou - orbou v smere vrstevnic (2017)

B- vystavané terasy - suché múriky (2017)
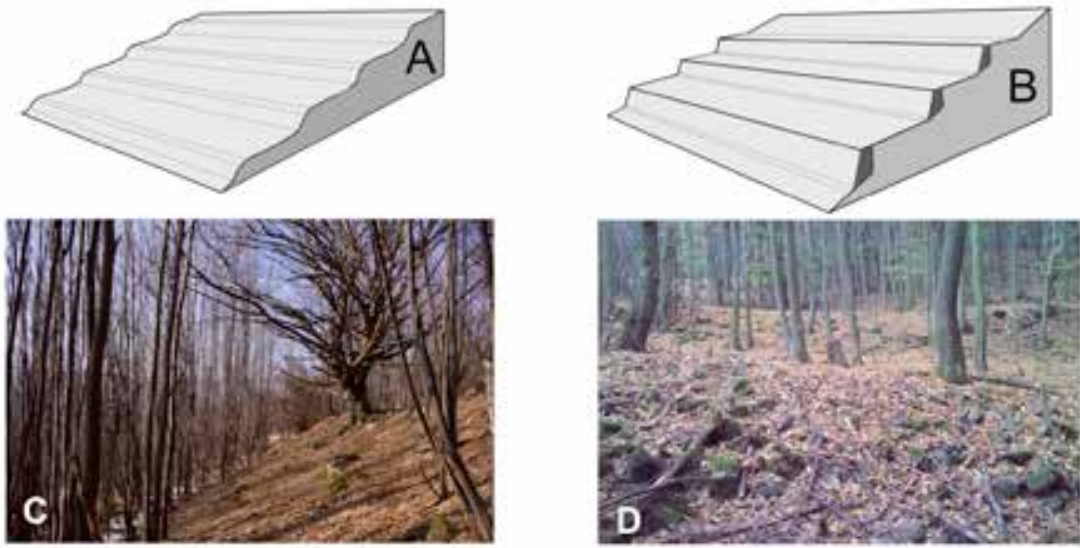

C - terasy s drevinami v historických mapách (mapa: 1810 - 1869; fotka 2017) D - terasy bez drevin (mapa:1952 - 1957; fotka 2010)
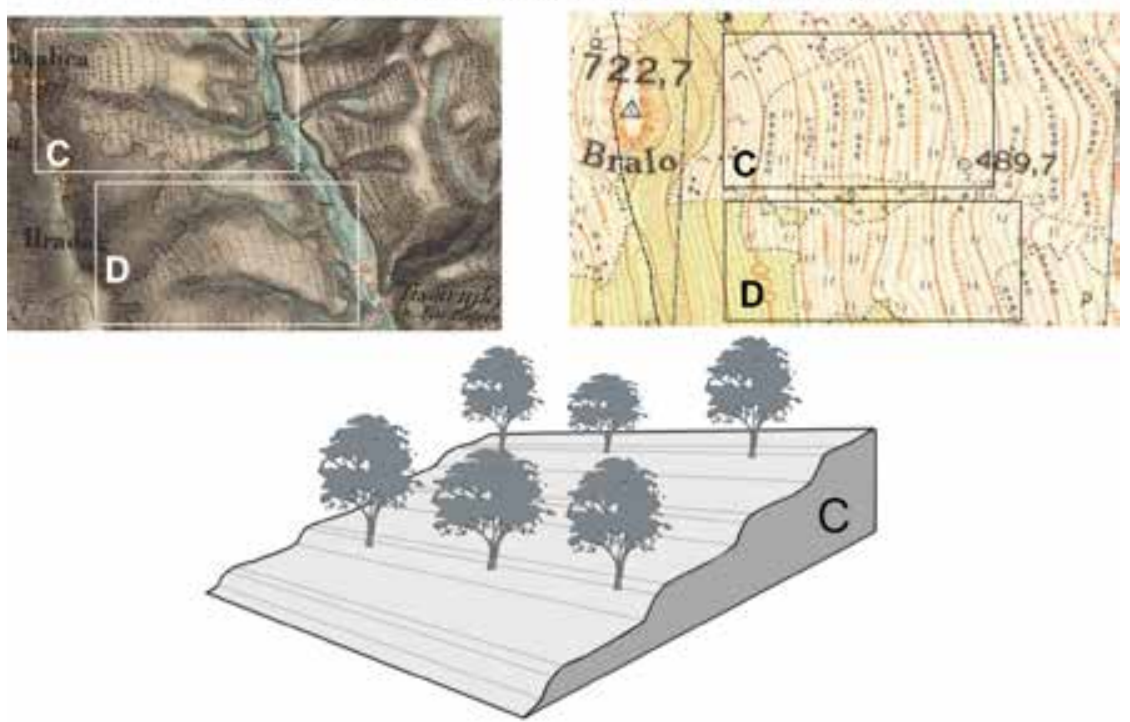

Obr. 3. Typy pol’nohospodárskych terás. A - nespevnené; B - spevnené (suchý múrik); C - teleso terasy s drevinami; D - teleso terasy bez drevín, zobrazené v historických mapách, fotografiách z terénneho prieskumu (2010 a 2017) a 3D modeloch. Abb. 3. Typen landwirtschaftlicher Terrassen. A - unbefestigte; B - befestigte (Trockenmauer); C - Terrassenkörper mit Gehölzen; D - Terrassenkörper ohne Gehölze, dargestellt auf historischen Karten, Fotos von der Geländeuntersuchung (2010 und 2017) und als 3D-Modell. 
terasách zobrazujú aj historické mapy (1810-1869; 1952-1957). Niektoré terasy boli bez prítomnosti drevín (obr. 3:D).

V lokalite Zakrovo (predmetný modrý polygón s terasami sa nachádza pod vrchom Končitý hrádok) sme z historickej katastrálnej mapy (1866) zistili, že priemerná výmera pozemkov na terasách bola $2116,79 \mathrm{~m}^{2}$; minimálna výmera bola $406,31 \mathrm{~m}^{2}$ a maximálna $71000,00 \mathrm{~m}^{2}$ (priemerná vel'kost' bola 3,57 ha; obr. 4). Z uvedeného vyplýva, že v minulosti sa hospodárilo na vel'mi malých pozemkoch. To bolo na jednej strane výhodné z hl'adiska rôznorodosti krajinnej pokrývky a ekologickej kvality krajiny, ale na druhej strane rozdrobené parcely a majetkovo nevysporiadané pozemky spôsobovali a aj v súčasnosti spôsobujú opúštanie terás, ako sme sa dozvedeli počas terénnych prieskumov z rozhovorov od miestnych obyvatel'ov. Fragmentované a výmerou malé parcely rozmiestnené na rôznych častiach katastrálneho územia patriace $\mathrm{k}$ určitej rodine nie sú zaujímavé ani z hl'adiska podnikania v pol'nohospodárstve.

Počas terénnych prác sme merali parametre terás v lokalite Zakrovo. V tranzekte dlhom $747 \mathrm{~m}$ (najnižší bod $450 \mathrm{~m} \mathrm{n.m.} \mathrm{/} \mathrm{najvyšší} \mathrm{bod} 600 \mathrm{~m} \mathrm{n.m.)} \mathrm{sme} \mathrm{identifikovali} \mathrm{spolu} 25$ terás (z toho dve korešpondujú s cestou); priemerný sklon prirodzeného svahu bol $14^{\circ}$ a priemerný sklon terás $9^{\circ}$, čo zodpovedá sklonu svahu vyhovujúceho pre využívanie pozemku formou striedania ornej pôdy a trvalých trávnych porastov. Celkovo sedem terás malo výšku do $0,5 \mathrm{~m}$. Stredne vysokých terás bolo spolu desat', z tohto pät' terás malo výšku do $1 \mathrm{~m}$ a 5 do $1,5 \mathrm{~m}$. Vysokých terás bolo spolu osem, $\mathrm{z}$ toho pät' terás malo výšku do $2 \mathrm{~m}$ a výšky $2,5 \mathrm{~m}, 3 \mathrm{~m}$ a $4 \mathrm{~m}$ mali jednotlivé terasy (obr. 5).

\section{Rozšírenie terás vzhl'adom na prírodné podmienky, využitie zeme a kvalitu pôdy v historic- kých súvislostiach}

V porovnaní súčasného využitia zeme (obr. 6:A, B) so situáciou na mape z I. vojenského mapovania (1764-1787; obr. 2:A) môžeme konštatovat', že aj v minulosti a aj v súčasnosti vo vegetačnej jednotke karpatských dubovo-hrabových lesov prevažovalo pol’nohospodárske využitie zeme $\left(62 \%\right.$ z $5 \mathrm{~km}^{2}$; tab. 1). V tejto vegetačnej jednotke je aj najväčšia hustota terás na pol’nohospodárskej pôde $\left(9,7 \mathrm{~km} / \mathrm{km}^{2}\right)$. V južnej časti katastra preto predpokladáme aj vznik najstarších neskorostredovekých terás, ktoré sa viažu na osídl’ovanie doliny Tisovníka, od druhej polovice 16. storočia.

Plošne najrozsiahlejšia bola jednotka podhorských bukových lesov $\left(20,1 \mathrm{~km}^{2}\right)$. Podla historickej mapy z II. vojenského mapovania (1810-1869; obr. 2:B) sa lesy v tejto vegetačnej jednotke vyskytovali iba miestami, a to v údoliach, výmol'och a stržiach ústiacich do potoka Tisovník, alebo na miestach s bralným reliéfom či strmými svahmi. Pol’nohospodárske využitie malo v súčasnosti $6,9 \mathrm{~km}^{2}(34 \%)$ z celkovej rozlohy vegetačnej jednotky. Z hladiska množstva terás sa tu vyskytuje najviac terás $(64,7 \mathrm{~km}) \mathrm{v}$ pol'nohospodárskej krajine $\mathrm{z}$ celého skúmaného územia a majú porovnatel'nú hustotu $9,4 \mathrm{~km} / \mathrm{km}^{2}$ oproti južne situovanej jednotke. Zaujímavé je, že od druhej polovice 19. storočia až do súčasnosti sa v tejto vegetačnej jednotke najviac zmenilo pol'nohospodárske využitie na lesohospodárske (obr. 6:A).

Bukové a jedl'ovo-bukové lesy zaberajú porovnatel'nú rozlohu $\left(6,1 \mathrm{~km}^{2}\right)$ ako karpatské dubovo-hrabové lesy $\left(5 \mathrm{~km}^{2}\right)$, avšak pol'nohospodárska pôda $\mathrm{v}$ jednotke zaberá iba $2,3 \mathrm{~km}^{2}(38 \%$ z $6,1 \mathrm{~km}^{2}$ ). Pri porovnaní súčasného využitia zeme (obr. 6:A, B) so situáciou v mape z I. a II. vojenského mapovania (obr. 2:A, B) je zrejmé, že aj v neskorom stredoveku a novoveku bolo toto územie z vel'kej časti zalesnené. Rozptýlené osídlenie trvalého charakteru označené v mape (obr. 2:B) tu vzniklo síce už počas 19. storočia, avšak zahustené do súčasnej podoby bolo až na prelome 19. a 20. storočia, čo dokladáme porovnaním máp z II. vojenského mapovania a vojenskej mapy 50-tych rokov minulého storočia (obr. 2:B). Preto aj súvisiace pol'nohospodárske terasy sú na severe skúmaného územia pravdepodobne najmladšie a boli vybudované na pol’nohospodárskej pôde s najnižším produkčným potenciálom reprezentovaným menej a málo produkčnými trávnymi porastmi (T2 a T3). V tejto najsevernejšej jednotke (nadmorské výšky sa pohybujú medzi $650-800 \mathrm{~m} \mathrm{n}$. m.) sa nachádza v pol’nohospodárskej krajine $14,6 \mathrm{~km}$ terás s hustotou $6,3 \mathrm{~km} / \mathrm{km}^{2}$. 


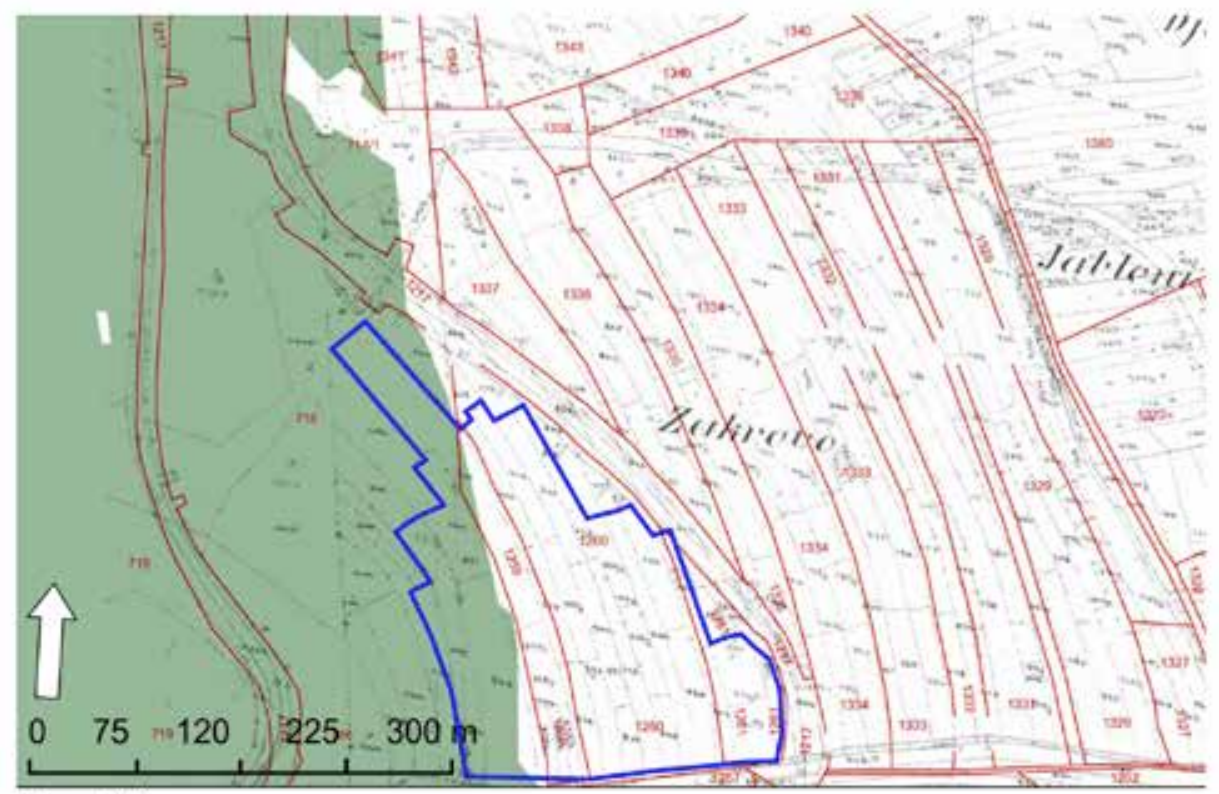

\section{Vysvetlivky}

— Parcely historickẻho rozdelenia pozemkov z roku 1866 (Štátny archiv, Banská Bystrica)

Parcely súčasného rozdelenia pozemkov z roku 2018 (ÚGKK SR 2018)

(Katastrálny portál, mapa dostupná cez WMS službu ESKN:

https:/ikataster.skgeodesy.sk/eskn/services/NR/kn_wms_orto/MapServer/WmsServer)

Lesné pozemky (NLC SR, 2018):

http://gis.nlcsk.org/arcgis/services/nspire/DrevinoveZlozenie/MapServer/WmsServer?

Lokalita Zakrovo s výskytom terás:

- stredne vysokých (do 1,5 m)
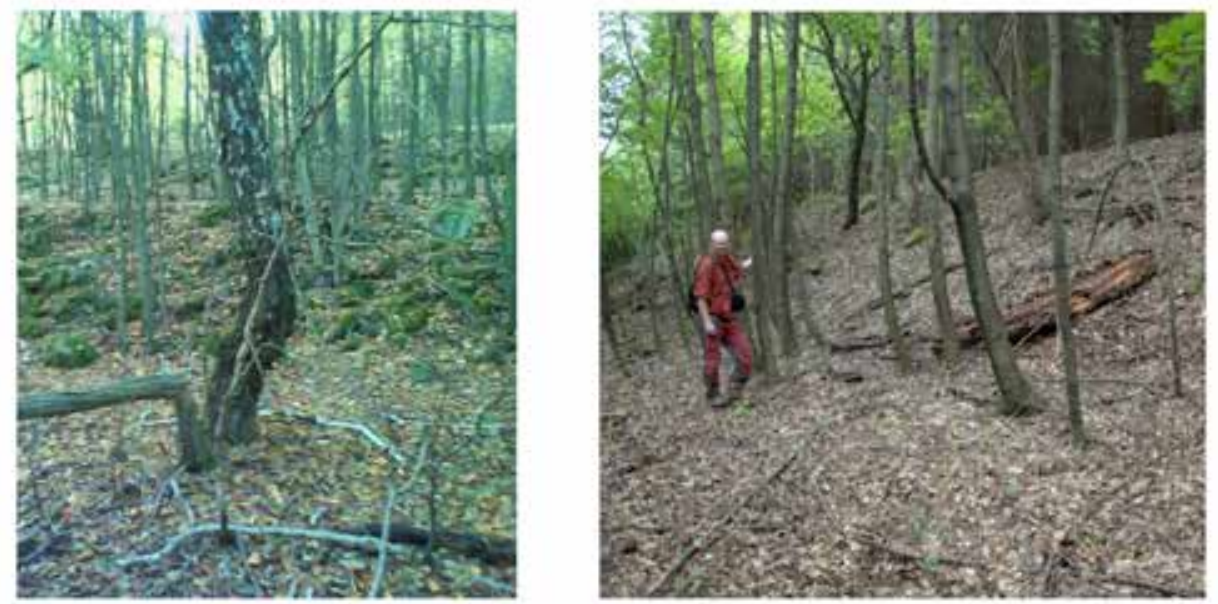

Obr. 4. Pol’nohospodárske terasy $v$ historickej mape z roku 1866 (Štátny archív, Banská Bystrica, 2015), v súčasnej katastrálnej mape (Portál ESKN 2018; NLC 2018) a v teréne v lokalite Zakrovo pod vrchom Končitý hrádok (701 m n. m.). Abb. 4. Landwirtschaftliche Terrassen auf einer historischen Karte aus dem Jahre 1866 (Staatl. Archiv, Banská Bystrica, 2015), auf einer aktuellen Katasterkarte (Portal ESKN 2018; NLC 2018) und im Gelände der Fundstätte Zakrovo am Fuß des Berges Končitý Hrádok (701 m ü. NHN). 


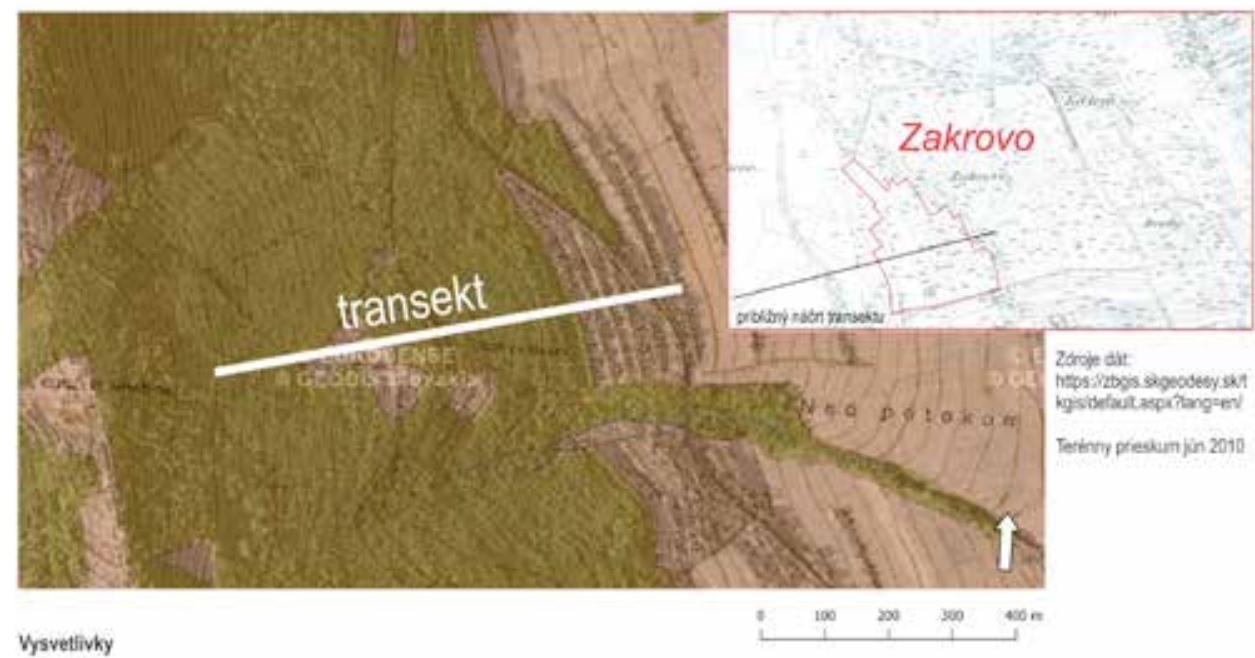

\section{-.-. Katastráne úcemie \\ 페마 Poinchospodárske terasy}

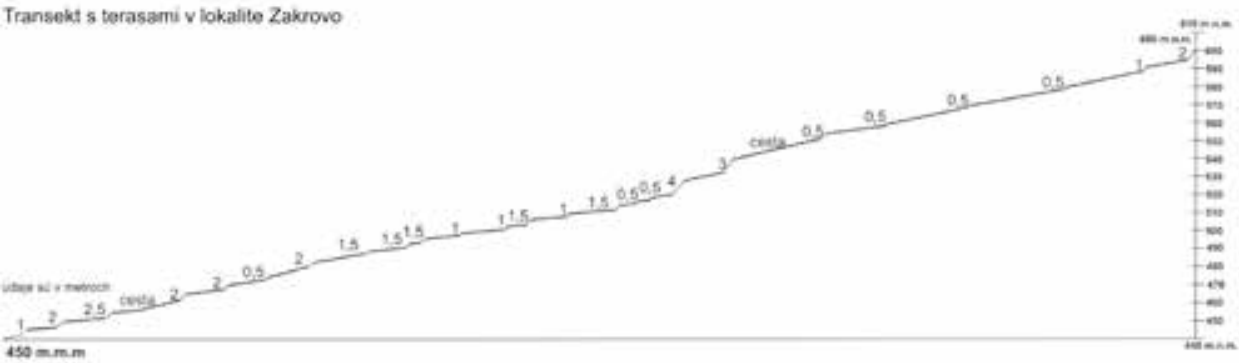

Orignal meeka $1: 7000$

Obr. 5. Tranzekt terás meraných v teréne (2010), ktorý zachytáva terasy zaznamenané v súčasnej i historickej mape, ako aj terasy určené iba v teréne.

Abb. 5. Transekt von im Gelände vermessenen Terrassen (2010), das Terrassen auf einer aktuellen und einer historischen Karte sowie nur im Gelände bestimmte Terrassen erfasst.

\begin{tabular}{|c|c|c|c|c|c|}
\hline \multirow[b]{2}{*}{$\begin{array}{l}\text { Les (ostatné lesné pozemky; } \\
\text { pôda pokrytá lesom nezarade- } \\
\text { ná do lesného pôdneho fondu, } \\
\text { ani do TPK) }\end{array}$} & \multirow[t]{2}{*}{$\begin{array}{l}\text { Výmera plochy } \\
{\left[\mathrm{km}^{2}\right]}\end{array}$} & \multirow[t]{2}{*}{$\begin{array}{l}\text { Dížka terás } \\
{[\mathrm{km}]}\end{array}$} & \multicolumn{3}{|c|}{$\begin{array}{l}\text { Jednotky potenciálnej prirodzenej vegetácie zastúpené } \\
\text { v TPK }\left[\mathrm{km}^{2}\right]\end{array}$} \\
\hline & & & $\begin{array}{l}\text { Karpatské } \\
\text { dubovo-hrabové } \\
\text { lesy }\end{array}$ & $\begin{array}{l}\text { Podhorské bukové } \\
\text { lesy }\end{array}$ & $\begin{array}{l}\text { Bukové a jedlo- } \\
\text { vo-bukové lesy }\end{array}$ \\
\hline & 18,1 & 86,1 & 1,9 & 13,2 & 3,8 \\
\hline Pol'nohospodárska pôda s TPK & 12,3 & 109,5 & 3,1 & 6,9 & 2,3 \\
\hline Sídlo & 0,8 & 0,9 & & & \\
\hline Katastrálne územie & 31,2 & 196,5 & 5 & 20,1 & 6,1 \\
\hline
\end{tabular}

Tab. 1. Zastúpenie pol’nohospodárskych terás v kategóriách súčasného využitia zeme a výmera jednotiek potenciálnej prirodzenej vegetácie v katastrálnom území.

Tab. 1. Vorkommen landwirtschaftlicher Terrassen in den Kategorien der gegenwärtigen Bodennutzung und Ausmaß potenzieller natürlicher Vegetationseinheiten im Katastergebiet. 


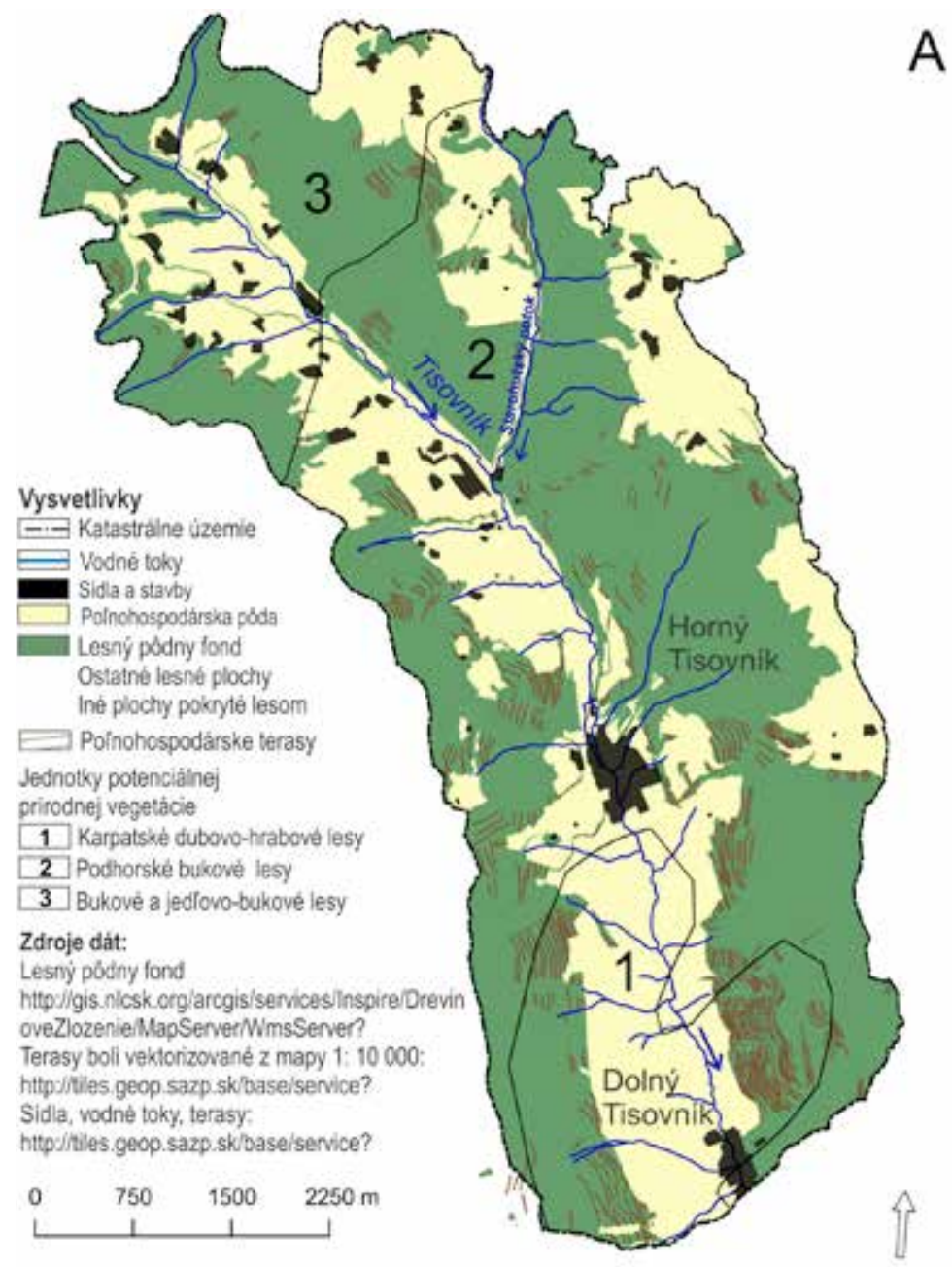

Obr. 6. Terasy porastené lesom, prevažne na lesnom pôdnom fonde (A). Pol’nohospodársky potenciál využitia krajiny, výskyt terás $v$ jednotkách potenciálnej prirodzenej vegetácie (B).

Celkovo najväčšiu plochu v pol’nohospodárskej krajine zaberajú menej produkčné trvalé trávne porasty $\left(\mathrm{T} 2 ; 4,5 \mathrm{~km}^{2}\right)$ a nachádza sa tu aj naviac terás $(52,5 \mathrm{~km})$, z toho $33 \mathrm{~km}$ je vo vegetačnej jednotke podhorských bukových lesov. Druhé najviac zastúpené sú málo produkčné trvalé trávne porasty $\left(\mathrm{T} 3 ; 3 \mathrm{~km}^{2}\right)$, ktoré prevažujú $\mathrm{v}$ podhorských bukových lesoch $\left(1,8 \mathrm{~km}^{2}\right)$ $\mathrm{s}$ dížkou terás $19,5 \mathrm{~km}$ a v bukových a bukovo-jedlových lesoch $\left(1,2 \mathrm{~km}^{2}\right) \mathrm{s}$ dížkou terás $11 \mathrm{~km}$ (tab. 2). Z uvedeného vyplýva, že pol'nohospodárska krajina má potenciál hlavne na extenzívne využívanie formou trvalých trávnych porastov (tab. 2; obr. 6:B). Avšak existuje tu potenciál na striedavé využívanie pol'nohospodárskej pôdy formou trvalých trávnych porastov a ornej pôdy (O6, O7 a OT1-OT3; tab. 2), a to hlavne v jednotke karpatských dubovo-hrabových lesov a na nive potoka Tisovník. 


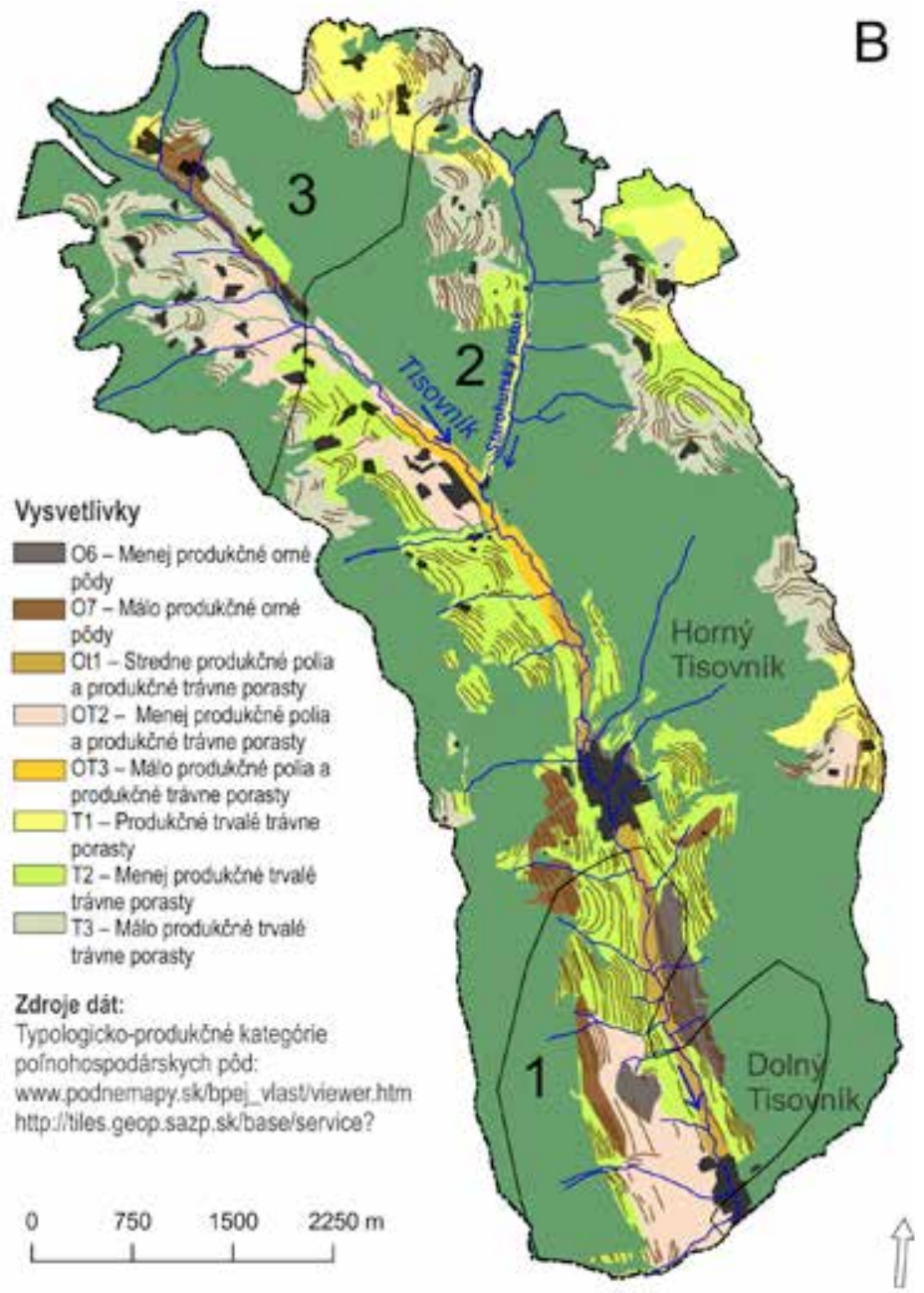

Abb. 6. Waldbedeckte Terrassen, überwiegend auf Waldbodenbestand (A). Landwirtschaftliches Potenzial der Landschaftsnutzung, Vorkommen von Terrassen in potenziellen natürlichen Vegetationseinheiten (B).

\section{Interpretácia environmentálnych dejín pol'nohospodárskej krajiny s terasami}

Katastrálne územie patrí medzi pol’nohospodársky znevýhodnené oblasti, hlavne kvôli nadmorskej výške, sklonu svahov a plytkým pôdam na neovulkanickom substráte, ktoré počas letných mesiacov trpia suchom. Na druhej strane, celková dížka terás $(195,6 \mathrm{~km})$ aj ich hustota $\left(6,3 \mathrm{~km} / \mathrm{km}^{2}\right.$; tab. 1) indikujú intenzívnu pol'nohospodársku činnost' v katastrálnom území, ktorá tu prebiehala $\mathrm{v}$ minulosti. Na základe rozboru archívnych materiálov predpokladáme, že nielen pol’nohospodárstvo dominujúce v časti skúmaného územia patriaceho do Modrokamenského panstva, zamerané na produkciu pol'nohospodárskych plodín spôsobilo prvotné rozširovanie terás od polovice 16. storočia (hlavne v dubovo-hrabovej jednotke potenciálnej prirodzenej vegetácie a jednotke podhorských bukových lesov). Aj ked'v tejto Modrokamenskej časti boli terasy štatisticky významnejšie zastúpené ako v Divínskej časti (Slámová et al. 2017), v neskoršom 


\begin{tabular}{|c|c|c|c|c|c|c|c|c|}
\hline 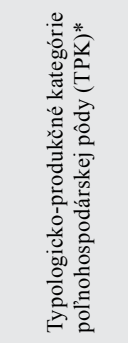 & 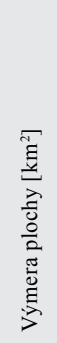 & 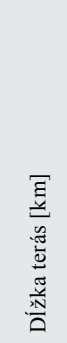 & 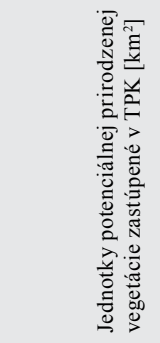 & 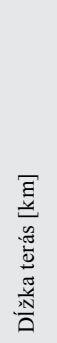 & 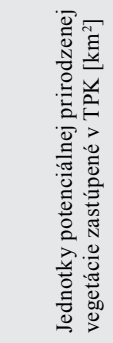 & 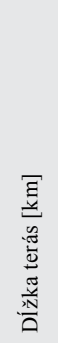 & 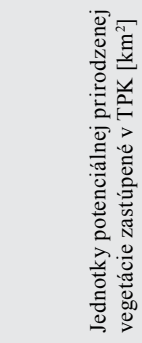 & 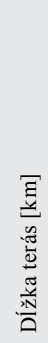 \\
\hline & & & \multicolumn{2}{|c|}{ Karpatské dubovo-hrabové lesy } & \multicolumn{2}{|c|}{ Podhorské bukové lesy } & \multicolumn{2}{|c|}{ Bukové a jedl'ovo-bukové lesy } \\
\hline TPK-O6 & 0,6 & 6,1 & 0,4 & 3,1 & 0,2 & 3 & - & - \\
\hline $\mathrm{TPK}-\mathrm{O} 7$ & 0,6 & 3,9 & 0,3 & 2,2 & 0,1 & 1,4 & 0,2 & 0,3 \\
\hline TPK-OT1 & 0,5 & 1,1 & 0,3 & 0,8 & 0,2 & 0,3 & - & - \\
\hline TPK-OT2 & 1,5 & 7 & 0,7 & 4,5 & 0,5 & 2,1 & 0,3 & 0,4 \\
\hline TPK-OT3 & 0,3 & 0,2 & - & - & 0,3 & 0,2 & - & - \\
\hline TPK-T1 & 1,3 & 8,2 & - & - & 0,8 & 5,4 & 0,5 & 2,8 \\
\hline $\mathrm{TPK}-\mathrm{T} 2$ & 4,5 & 52,5 & 1,4 & 19,4 & 3 & 33 & 0,1 & 0,1 \\
\hline TPK-T3 & 3 & 30,5 & - & - & 1,8 & 19,5 & 1,2 & 11 \\
\hline Spolu TPK & 12,3 & 109,5 & 3,1 & 30 & 6,9 & 64,9 & 2,3 & 14,6 \\
\hline
\end{tabular}

Tab. 2. Zastúpenie pol'nohospodárskych terás (dížka) v typologicko-produkěných kategóriách pol'nohospodárskej pôdy a v jednotkách potenciálnej prirodzenej vegetácie na pol'nohospodárskej pôde.

Tab. 2. Vorkommen landwirtschaftlicher Terrassen (Länge) in den typologisch-produktiven Kategorien des Agrarbodens und in potenziellen natürlichen Vegetationseinheiten auf dem Agrarboden.

období, približne od druhej polovice 18. storočia, to bol práve prudko sa rozvíjajúci priemysel a remeslá, ktoré spôsobili aj zintenzívnenie pol'nohospodárstva a budovanie terás. Drevospracujúci priemysel expandoval a ako napríklad udáva Martuliak $(2006,46)$, vodná píla na potoku Tisovník vytvárala pracovné príležitosti priamo v doline, ako i sklársky priemysel a súvisiace remeslá. Priemyselno-remeselné aktivity spôsobili významnejší rast miestnej populácie a súvisiace zväčšovanie rozlohy terás a ich prenikanie až do najsevernejších častí územia. Bolo to v období, ked' tu priemyselná činnost' vrcholila, a to na prelome 19. a 20. storočia. S rozvojom priemyslu v severnej, dovtedy neosídlenej časti začali v 18. storočí vznikat' usadlosti (Borovszky 1911, 14, 41). Na neskorší horizont odlesňovania záveru doliny Tisovníka poukazuje aj menšia hustota agrárnych terás a ich bezprostredná blízkost’ pri jednotlivých osadách (obr. 6). Tu bol síce produkčný potenciál pol’nohospodárskej pôdy najnižší a prevažovali tu málo produkčné trvalé trávne porasty (T3), avšak dopyt po obžive nútil l'udí kultivovat' aj málo produkčné pôdy a spôsobil rozšírenie terás aj v relatívne vysokých vrchovinných polohách $(600-750 \mathrm{~m} \mathrm{n} . \mathrm{m}$.).

Terasy vznikali v území: 1) spontánne pri dlhodobej kultivácii ornej pôdy na miernejších svahoch vrstevnicovou orbou, alebo 2) boli úmyselne budované za účelom vytvorenia priaznivých sklonových podmienok najmä pre ornú pôdu, aby sa zabránilo erózii pôdy a jej odnosu počas búrkových situácií. Identifikácia úmyselne vytvorených stavaných terás je v teréne problematická, pokial' nie je vidno samotný múr, ako napríklad na obr. 3:B (často je zasypaný zemou), pretože sú tvarovo totožné so samovol’ne vytvorenými terasami a pri ich odhalení je nutné použit' deštrukčné metódy (obr. 7), ako zist'ovali Slámová et al. (2015) pri výskume terás v katastrálnom území Budiná, v pohorí Ostrôžky (vzdušnou čiarou približne $10 \mathrm{~km}$ severovýchodne od Horného Tisovníka).

Pri terénnom prieskume v roku 2010 sme zistili aj výskyt takých terás, ktoré neboli zobrazené v mapách, a to ani v historickej katastrálnej mape z roku 1866. Preto existuje predpoklad, 
Deštrukčné metódy zistovania vzniku terás. Na obrázku je terasa vytvorená spontánne dlhodobou kultiváciou.

Z terás boli odoberané vzorky pódy na analẏzu skeletu v pôde (výskum publikovaný: Slámová et al., 2015).
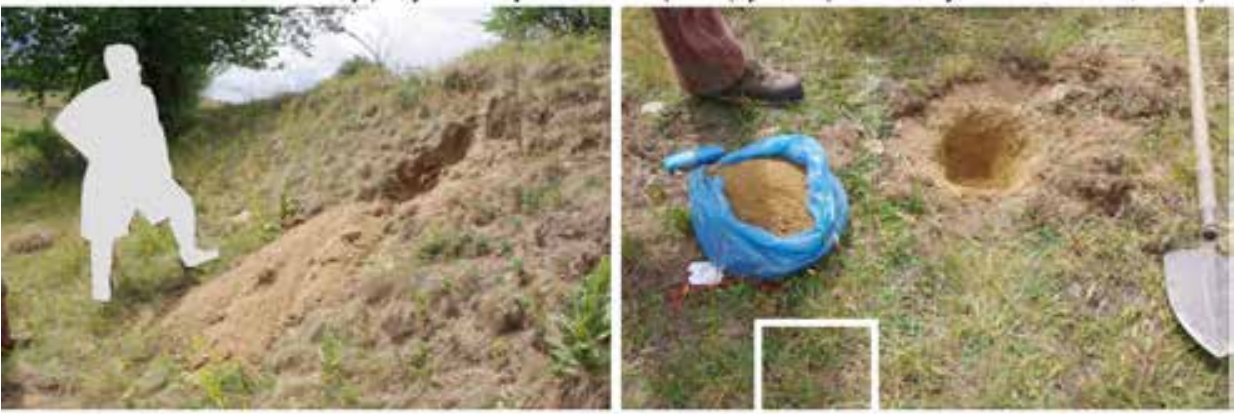

Vrch Jasenie (771 m n. m.) s polnohospodárskymi terasami v katastrálnom územi Budiná, Ostrôżky.

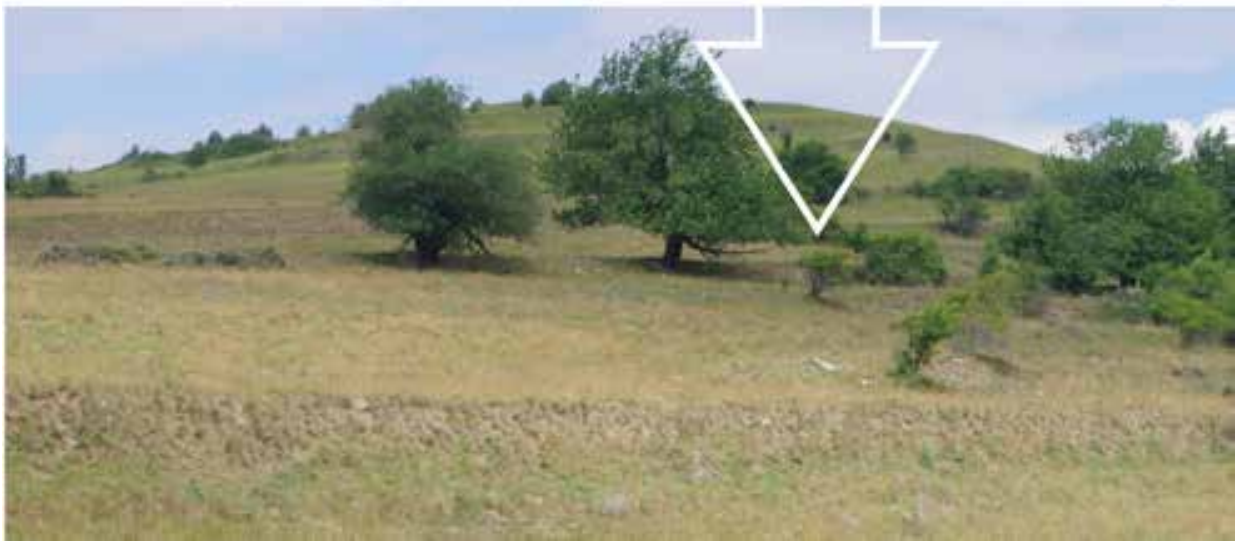

Obr. 7. Zist'ovanie pôvodu vzniku terás v katastrálnom území Budiná. Podl’a Slámová et al. 2015.

Abb. 7. Festellung der Ursachen für die Entstehung der Terrassen im Katastergebiet Budiná. Nach Slámová et al. 2015.

že terás je v území viac, ako sme zistili vektorizovaním terás z máp v tomto príspevku. Identifikácia reálneho počtu terás v území je súčasne aj námet pre d’alší výskum. Napríklad s využitím moderných bezkontaktných technológií akou je aj bezpilotné letiace zariadenie (z anglického Unmanned Aerial Vehicles - UAV) je možné preskúmat' aj zalesnené územie (najlepšie zo slabším zápojom korún stromov) v relatívne krátkom čase a s pomerne vysokou presnostou meraní polohy a výšok (pod $20 \mathrm{~cm}$; Tomaštík et al. 2017).

Terasy upravujú sklonové pomery pol’nohospodárskej pôdy a zlepšujú aj iné produkčné vlastnosti (Slámová et al. 2015, 52-53). Slámová (2013, 68, obr. 32) dokumentovala parametre terás na piatich výskumných lokalitách v pohorí Ostrôžky (štyri v katastrálnom území Budiná a jedna v Hornom Tisovníku). Autori zistili, že priemerný sklon pôvodného svahu bol $14^{\circ}$ a po úprave terasovaním dosahoval $11^{\circ}$ (priemerná výška terasového stupňa bola $1,5 \mathrm{~m}$ a jeho sklon $\left.31^{\circ}\right)$. V prípade tranzektu v skúmanom území bol sklon pôvodného terénu $14^{\circ}$ a terasovaného $9^{\circ}$, čo je z hl'adiska pol’nohospodárskeho využívania sklon vhodný pre striedavé polia a trvalé trávne porasty (podl'a metodiky VÚPOP, 2011). Tu musíme skonštatovat' aj upozornit', že zmena sklonových pomerov prirodzeného terénu terasovými úpravami nie je zohl'adnená v oficiálnej klasifikácii typologicko-produkčných kategórií pol’nohospodárskych pôd.

V súčasnosti v katastrálnom území prevažuje lesohospodársky využívaná krajina $(18,1$ km²). Výsledky tejto práce dokazujú, že v území existuje produkčný potenciál na využívanie terás 
formou ornej pôdy (O6-O7) prevažne na rovinatej nive potoka Tisovník, a potom v južnej časti územia (v okolí obce Dolný Tisovník a južne od obce Horný Tisovník), korešpondujúci s potenciálnymi prirodzenými dubovo-hrabovými lesmi, ako aj potenciál striedavých polí a trvalých trávnych porastov (OT1-OT3; obr. 6:B). Na sever od obce Horný Tisovník a v severnej časti katastrálneho územia s roztrúseným osídlením prevažuje potenciál trvalých trávnych porastov (T1-T3). Zistili sme, že v južnej polovici skúmaného územia (približne po obec Horný Tisovník) existovali prírodné predpoklady pre rozvoj pol’nohospodárstva, čo pravdepodobne spôsobilo prvotný vznik terás $\mathrm{v}$ tomto území a ich postupné rozširovanie $\mathrm{v}$ smere $\mathrm{z}$ juhu územia na sever.

Intenzívne pol’nohospodárske využitie terás, ako aj výskyt ornej pôdy v území dokazujú aj archívne údaje (Borovszky 1911; Alberty et al. 1989; Martuliak 2006). Podla historických údajov pôda odnesená vodou počas zrážok bola spät' na svahy vyvážaná povozom alebo vynášaná ručne v košíkoch (Alberty et al. 1989, 308-312). Na zlú kvalitu pôdy a strmost' svahov upozorn̆ujú aj vyššie spomenuté predurbárne zápisnice spísané v júni roku 1771 pre tzv. tereziánsky urbár (Országgyülés Hivatala 2018). V zápisniciach predstavitelia Horného aj Dolného Tisovníka označili svoju pôdu (chotár) za slabo úrodnú a vel'mi kamenistú. Všetky tieto faktory ovplyvňovali charakter pol’nohospodárskej krajiny. Zostaveniu tereziánskeho urbára na konci 18. storočia predchádzalo spisovanie aktuálneho stavu a zistovanie poddanských pomerov v obciach formou dotazníka. V Hornom Tisovníku boli odpovede zapísané 4. júla 1771 a v Dolnom Tisovníku 6. júla 1771 (Országgyülés Hivatala 2018). Z hladiska opisu pol’nohospodárskej krajiny sú zaujímavé odpovede na štvrtú otázku, kde predstavitelia obcí cenzorovi odpovedali, ako vyzeral ich chotár. Predstavitelia Horného Tisovníka svoj chotár charakterizovali ako „,vrchovitý a skalnaty", a preto na obrábanie ornej pôdy a lúk museli vynaložit' vel’a sily. Ornú pôdu doslovne charakterizovali ako „skalnatú zem“, a preto museli kupovat’ vel’a železa na pluhy, kolesá a podkovy koní. Zo zápisnice vyplýva, že pestovali aj vel’a obilnín, ked’že v obci prevádzkovali dva mlyny. Predstavitelia Dolného Tisovníka charakterizovali svoj chotár vel'mi podobne: „Osada naša je vrchowista a skalnatá...“. Môžeme vylúčit, že odpovede zapísal a štylizoval jeden pisár, ked’že rukopisy sa odlišujú. Charakter a špecifiká pol'nohospodárstva v prvej polovici 18. storočia v severnom Novohrade opisuje na niekol'kých miestach vo svojom diele aj M. Bel (Bel 1742). Išlo o málo výnosné pol'nohospodárstvo vzhl'adom na nízku úrodnost' pôdy, svahovitost' polí a množstvo skál, a tiež z dôvodu nepriaznivých klimatických podmienok. Využíval sa iba dvojpol'ný systém pol'nohospodárstva a v klase obilia sa urodili len dve až tri zrná. Častým javom bola nepriazeň počasia, či už mrazy, sucho, krupobitie, ale aj erózia.

Na základe prírodných daností, archívnych údajov, ako aj dokázanej štatisticky významne vyššej koncentrácie terás $\mathrm{v}$ Modrokamenskom panstve, zameranom na pol'nohospodársku výrobu a pestovanie plodín (Slámová et al. 2017) predpokladáme, že terasy obyvatelia budovali hlavne za účelom získania ornej pôdy, až sekundárne pre ich využitie iba formou trávnych porastov. Môžeme konštatovat', že potenciál pre ornú pôdu či striedanie ornej pôdy a trvalých trávnych porastov tu existuje, ale na druhej strane už nie je v súčasnosti využitý. Podla údajov Štatistického úradu SR (2017) orná pôda zaberá plochu iba $1,6 \mathrm{~km}^{2}$. V území musela v minulosti existovat' dostatočná populácia, ktorá dokázala rozsiahly, približne $195 \mathrm{~km}$ dlhý systém terás vytvorit'. Táto populácia tu dnes už nie je a terasy sú z prevažnej väčšiny neobhospodarované.

Rozsiahly terasový systém nás prinútil zamysliet' sa nad tým, ako by ich bolo možné využívat' v súčasnosti a starat' sa o ne tak, aby ostali zachované nielen ako kultúrne a historické dedičstvo v obraze krajiny, ale aby plnili aj nad’alej dôležitú protieróznu funkciu. Horný Tisovník patrí v súčasnosti medzi ekonomicky marginálne oblasti kvôli svojej polohe vzhl'adom na významné sídelno-hospodárske centrá a dôležité dopravné línie (Horňák, Rochovská, 2007). Podl’a zistení autorov postoj miestnych obyvatel'ov k možnosti riešit' otázku nedostatku pracovných príležitostí je pozoruhodný. Situáciu riešia vyst'ahovaním sa do regiónov s lepšími možnost'ami získat' zamestnanie. To sa odzrkadl'uje v súčasnom hospodárskom využití krajiny, ktoré sa za posledných 150 rokov výrazne zmenilo. Z porovnania zastúpenia terás $\mathrm{v}$ lesoch $(86,1 \mathrm{~km}$ na rozlohe $\left.18,1 \mathrm{~km}^{2}\right)$ a pol'nohospodárskej krajine $\left(109,5 \mathrm{~km}\right.$ na rozlohe $\left.12,3 \mathrm{~km}^{2}\right) \mathrm{v}$ riešenom území $\left(31,2 \mathrm{~km}^{2}\right)$ vyplýva, že sú v oboch prípadoch zastúpené približne rovnomerne a je zrejmé, že 
v dôsledku slabnúcej pol'nohospodárskej činnosti sa historická pol'nohospodárska krajina opät' mení na les (tab. 1; obr. 6:A).

Aj ked' terasy v lesoch už nie sú pol’nohospodársky využívané (takmer polovica zo všetkých terás v území), plnia významnú vodozádržnú funkciu a spomal'ujú odtok vody z povodia. Okrem iného reprezentujú hmotné kultúrne, technické a historické dedičstvo, ktoré vyplynulo z intenzívneho pol'nohospodársko-priemyselného využívania krajiny za posledných 250-300 rokov, a preto by sa ako atrakcia $\mathrm{v}$ krajine mali stat' súčast'ou podnikatel'ských plánov v oblasti cestovného ruchu. Aby sme zachovali osobitý kultúrno-historický ráz krajiny, navrhujeme aktívne využívanie čo najväčšieho množstva terás, ktoré ešte nie sú porastené drevinami s pokryvnostou nad 50\% (podla kritérií, ktoré uvádzajú Špulerová et al. 2009 pre mapovanie historických agro-štruktúr v krajine), a to v okolí obcí Dolný a Horný Tisovník. Tu je možné terasy využívat' aj ako ornú pôdu, alebo je možné striedat' ornú pôdu s trvalými trávnymi porastmi. V bezprostrednom okolí lazov v severnej časti územia je doporučené hlavne kosenie a pasenie a mala by byt' zohl'adnená aj pešia dostupnost' terás do 10 minút, ako doporučujú Lieskovský et al. (2015, 80, tab. 2). Pol’nohospodárska pôda, ktorá ešte nie je zaradená v lese a nenachádza sa ani v bližšom okolí lazníckych usadlostí, ktorá je súčasne vzdialená od sídla a je porastená sukcesným drevinovým zárastom nad $50 \%$, by mala byt' delimitovaná do lesného pôdneho fondu.

Vo vzdialených a periférnych oblastiach je farmárstvo často iba jednou z mála ekonomických aktivít (Bohátová et al. 2016, 148). Práve diverzifikovaná, multifunkčná krajina, rešpektujúca biotopy a biodiverzitu je aktuálnym vzorom pre mnohé krajiny po celom svete (LovellJohnston 2009, 218; Roth-Kruse 2012, 9-23). S využitím agro-environmentálnych programov by mali byt' viac podporované malé a rodinné farmy. Okrem pol'nohospodárskej funkcie plnia funkciu hot-spotov v turistickej infraštruktúre vidieka. Inšpiratívne myšlienky implementácie krajinných hodnôt do pol'nohospodárskych aktivít by sa mali rozširovat' a stat' sa súčast'ou obchodných značiek miestnych a regionálnych pol’nohospodárskych produktov, no v neposlednom rade by mali byt' obsiahnuté v turistických sprievodcoch a spolupodiel'at' sa na vytváraní centier turistického ruchu (Kruse et al. 2017).

\section{Záver}

V histórii krajiny sa striedajú obdobia relatívnej stability s obdobiami jej transformácií. Počas týchto zmien vznikajú objekty, ktoré dokumentujú určitú vývojovú fázu a niekedy pretrvávajú do súčasnosti ako relikty (Renes 2015). V súčasnosti sa pol’nohospodárska krajina Horného Tisovníka mení na rozsiahlych plochách spät’ na les vplyvom absentujúceho manažmentu, a to aj v lokalitách vhodných na pol’nohospodárstvo, ako to dokazujeme v našich výsledkoch. Terasy sa postupne strácajú z obrazu krajiny a práve táto črta, ktorá by mohla byt' zaujímavá pre turistov, zaniká. Najefektívnejšia ochrana a manažment pol’nohospodárskej krajiny znamená ochranu lokálneho vedomostného systému, ktorý pretrváva $\mathrm{v}$ podobe tradičného spôsobu využívania zeme. Práve z tohto hladiska sú dôležité poznatky z environmentálnej histórie. Naše výsledky potvrdili, že v území existuje geo-klimatický gradient, ktorý mal vplyv na osídl’ovanie a pol’nohospodárske využívanie územia a na súvisiaci vznik terás v smere od najskoršieho osídlovania územia v najnižších nadmorských výškach na juhu až po najmladšie na severe, v najvyšších nadmorských výškach. V budúcom plánovaní využitia terás je nevyhnutné rešpektovat' prírodné limity prostredia vyjadrené $\mathrm{v}$ typologicko-produkčných kategóriách pol’nohospodárskych pôd a rovnako je potrebné akceptovat' informácie $\mathrm{z}$ historických prameňov, aby sa predišlo erózii pôdy, lebo podl’a archívnych údajov tu bola erózia bežným javom. Správnou delimitáciou funkčného využitia pozemkov je možné získat' adekvátnu finančnú podporu nielen do oblasti pol'nohospodárstva, ale aj lesného hospodárstva, ktoré v súčasnosti v území prevažuje. Množstvo terás v katastrálnom území Horného Tisovníka ho robí výnimočné nielen na Slovensku, a preto ich vhodná interpretácia a propagácia by mohla pomôct' prilákat' turistov. Kombinácia historickej identity a udržatel'nosti v krajinnom plánovaní je pre našu spoločnost' vel'kou výzvou (Larcher et al. 2017). 
Táto práca bola podporená vedeckou grantovou agentúrou MŠVVaŠ SR a SAV, grant VEGA č. 1/0868/18 „Inovatívne postupy mapovania antropogénnych a prírodných foriem terénu a reliéfu pri zist'ovaní stavu krajiny."

Projekt ERASMUS+ č. 2016-1-SK01-KA202-022502, "FEAL: multifunctional Farming for the sustainability of European Agricultural Landscapes", bol financovaný s podporou Európskej komisie. Táto publikácia reprezentuje výlučne názor autora a Komisia nezodpovedá za akékol'vek použitie informácií obsiahnutých v tejto publikácii.

\section{Literatúra}

AGNOLETTI, M., (2015): Features Analysis of Dry Stone Walls of Tuscany (Italy). Sustainability 7, 1388713903. https://doi.org/10.3390/su71013887

ALÁČ, J., 2015: Tu spočíva kvet, čo zanechal svet... Novohradské l'udové náhrobníky a ich prezentácia v Hornom Tisovníku. Horný Tisovník - Banská Bystrica.

ALBERTY, J. et al., 1989: Alberty, J.-Oždáni, O.-Sásky, L.-Točík, A., Novohrad - dejiny. Martin.

BALASA, G., 1960: Praveké osídlenie stredného Slovenska. Martin.

BEL, M., 1742: Notitia Hungariae Novae Historico-Geographica IV. Viennae.

BELJAK, J. et al., 2015: Beljak, J.-Beljak Pažinová, N.-Mitáš, V., Stredné a Horné Poiplie. Svedectvo Archeológie. Nitra.

BEZÁK, P.-HALADA, L., 2010: Sustainable management recommendations to reduce the loss of agricultural biodiversity in the mountain regions of NE Slovakia, Mountain Research and Development 30(3), 192-204. https://doi.org/10.1659/MRD-JOURNAL-D-10-00023.1

BOHÁTOVÁ, Z. et al., 2016: Bohátová, Z.-Schwarcz, P.-Schwarczová, L.-Bandlerová, A.-Tl’čik, V., Multifunctionality Interactions and Implications: The Case of the Podkylava Village (Western Slovakia), European Countryside 8(2), 147-159. https://oi.org/10.1515/euco-2016-0012

BOROVSZKY, S., ed., 1911: Magyarorszak Varmegyei es Varosai - Nograd Varmegye. Budapest.

DEMEK, J., 1987: Obecná geomorfologie. Praha.

DVOŘÁK, T. et al., 2014: Dvořák, T.-Fasora, L.-Chocholáč, B.-Malý, T.-Nečasová, D.-Stoklásková, Z.Wihoda, M., Úvod do studia dějepisu. 1. díl. Brno.

ECO, U., 1997: Jak napsat diplomovou práci. Olomouc.

EISNER, J., 1933: Slovensko v pravěku. Bratislava.

GEODETICKÝ A KARTOGRAFICKÝ ÚSTAV (GKÚ), 2018: GEOPORTÁL, ZBGIS - Mapový klient. Dostupné z: https://zbgis.skgeodesy.sk/tkgis/default.aspx?lang=en/, cit. 2. 2. 2018.

GERBER, E. W., 1974: Methodology in Historical Research. Exercise \& Sport Sciences Reviews 2(1), $335-356$.

HANUŠIN, J., 2003: Landscape Ecological Aspects of the Collectivized Agricultural Landscape in View of Sustainability, Ekológia 22, 367-376.

HENDRIKS, K. et al., 2000: Hendriks, K.-Stobbelaar, D. J.-Van Mansvelt, J. D., The appearance of agriculture: An assessment of the quality of landscape of both organic and conventional horticultural farms in West Friesland, Agriculture, Ecosystems \& Environment 77(1-2), 157-175. https://doi.org/10.1016/ S0167-8809(99)00100-0

HOFFMAN, R. C., 2014: An Environmental History of Medieval Europe (Cambridge Medieval Textbooks). Cambridge.

HOLEC, R., 2014: Človek a príroda v „dlhom“ 19. storočí. Bratislava.

HORŇÁK, M.-ROCHOVSKÁ, A., 2007: Selected Quality Life Aspects in Inner Perriferies of Slovakia, Geographia Cassoviensis 1, 55-60.

HREŠKO, J. et al., (2010): Hreško, J.-Kanasová, D.-Petrovič, F., Landscape archetypes as the elements of Slovak historical landscape structure, Ekológia 29, č. 2, 158-173. https://doi.org/10.4149/ekol_2010_02_158

HROCH, M. et al., 1985: Úvod do studia dějepisu. Praha.

HRONČEK, P., 2014: Environmental history of the landscape. Case study of Brusno. Banská Bystrica.

- 2014a: História krajiny a environmentálne dejiny krajiny. In: Zborník Kysuckého múzea 16, 9-21. Čadca.

- 2014b: Možnosti využitia interdisciplinárnych výskumných metód v histórii, pri výskume historickej krajiny a historických krajinných prvkov. In: Zborník Kysuckého múzea 16, 21-64. Čadca.

- 2015: Environmentálne dejiny lesnej krajiny v doline Štiavničky v Nízkych Tatrách, Quaestiones rerum naturalium 2, č. 2, 91-115.

- 2017: Problematika environmentálnych dejín na Slovensku, Forum Historiae 11, 8-18. 
HUGHES, J. D., 2006: What is Environmental History? Cambridge.

IVAN, A., 1993: Reliéf krajiny jako součást životního prostředí a jeho narušování člověkem, Sborník České geografické společnosti 98, č. 3, 179-189.

IVANIČ, P., 2011: Stredoveká cestná siet’ na Pohroní a Poiplí. Nitra.

JELEČEK, L., 2010: Environmentální dějiny: jejich vznik, konceptualizace a institucionalizace (USA, Evropa a svět), Annales historici Presovienses 9, 247-274.

KAVULJAK, A. 1942: Dejiny lesníctva a drevárstva na Slovensku. Bratislava.

KORPEL, Š., 1989: Pralesy Slovenska. Bratislava.

KRIPPEL, E., 1986: Postglaciálny vývoj vegetácie na Slovensku. Bratislava.

KRUSE, A. et al., 2017: Kruse, A.-Renes, H.-Gaillard, B.-Sigura, M.-Slámová, M.-Belčáková, I.-Ambrožič, A.-Finale, R.-Canalicchio, M.-Rojas Pino, I.-Dreer, J.-Wenz J., Súhrnná správa. Súčasný stav vzt’ahu medzi trvalo udržatel'nými/multifunkčnými pol’nohospodárskymi praktikami a európskymi pol'nohospodárskymi krajinami. Zvolen.

LACIKA, J., 1999: Geomorfológia. Návody na cvičenia. Skriptum. Zvolen.

LARCHER, F. et al., 2017: Larcher, F.-Gullino, P.-Mellano, M. G.-Beccaro, G. L.-Devecchi, M., Integrating historical and social knowledge for restoring and planning traditional fruit landscape in Piedmont (Italy), Acta Horticulturae 1189, 339-342. https://doi.org/10.17660/ActaHortic.2017.1189.65

LASANTA, T. et al., 2013: Lasanta, T.-Arnaez, J.-Ruiz Flano, P.-Lana-Renault Monreal, N., Agricultural terraces in the Spanish Mountains: an abandoned landscape and a potential resource, Boletin de la Asociacion de Geografos Espanoles 63, 487-491.

LEWIS, M., 2014: And All Was Light? Science and Environmental History. In: The Oxford Handbook of Environmental History (Isenberg, A. C., ed.), 207-227. Oxford.

LIESKOVSKÝ, J. et al., 2015: Lieskovský, J.-Bezák, P.-Špulerová, J.-Lieskovský, T.-Koleda, P.-Dobrovodská, M.-Bürgi, M.-Gimmi, U., The Abandonment of Traditional Agricultural Landscape in Slovakia - Analysis of Extent and Driving Forces, Journal of Rural Studies 37, 75-84. https://doi.org/10.1016/j. jrurstud.2014.12.007

LOVELL, S. T.-JOHNSTON, D. M., 2009: Creating Multifunctional Landscapes: How Can the Field of Ecology Inform the Design of the Landscape? Frontiers in Ecology and the Environment 7, 212-220.

MAGYAR NEMZETI LEVÉLTÁR, 2010: Szakmai koordinációs központ. Dostupné z: http://adatbazisokonline.hu/en/adatbazis/az-1715_-evi-orszagos-osszeiras; http:// /adatbazisokol/adatbazis/az-1720_-evi-orszagos-osszeiras/, cit. 7. 3. 2018

MARTULIAK, P., 2006: Cez Tisovník vybíjaný chodník... Horný a Dolný Tisovník v minulosti a dnes. Banská Bystrica.

McNEILL, J. R., 2003: Observations on the Nature and Culture of Environmental History, Environment and History 42(4), 5-43.

MICHALKO, J. et al., 1985: Geobotanická mapa ČSSR, Slovenská socialistická republika - list Čadca. Bratislava.

- 1986: Geobotanická mapa ČSSR, Slovenská socialistická republika - textová čast'. Bratislava.

MIKLÓS, L.-HRNČIAROVÁ, T., edd., 2002: Atlas krajiny Slovenskej republiky. Banská Bystrica.

MYLLYNTAUS, T., ed., 2011: Thinking Through the Environment: Green Approaches to Global History. Cambridge.

NÁRODNÉ LESNÍCKE CENTRUM (NLC), 2018: Lesnícky GIS, NLC, Zvolen. Dostupné z: http://gis. nlcsk.org/lgis/, cit. 15. 2. 2018.

ORSZÁGGYÜLÉS HIVATALA, 2018. Mária Terézia Úrbéri Tabellák. Dostupné z: https://archives.hungaricana.hu/en/urberi/view/nograd, cit. 5. 5. 2018.

RENES, H., 2015: Historic Landscapes Without History? A Reconsideration of the Concept of Traditional Landscapes, Rural Landscapes: Society, Environment, History 2(1), 1-11.

RITCHE, D. A., 2003: Doing oral history: a practical guide. Oxford.

ROTH, M.-KRUSE, A., 2012: Agricultural landscapes Landscapes as cultural Cultural heritage Heritage a European View. In: National Association of Environmental Professionals [NAEP]: Science, Politics, and Policy: Environmental Nexus. Proceedings of the 37th Annual NAEP Conference, 9-23. Portland, Oregon.

SIMMONS, G., I. 1998: Towards an Environmental History of Europe. In: An Historical Geography of Europe (Butlin, R. A.-Dodgshon, R. A., edd.), 335-361. Oxford.

SLÁMOVÁ, M., 2013. Význam identifikácie historických krajinných štruktúr v krajinných typoch Slovenska. Vedecká monografia. Zvolen.

SLÁMOVÁ, M. et al., 2015: Slámová, M.-Jakubec, B.-Hreško, J.-Beláček, B.-Gallay, I., Modification of the potential production capabilities of agricultural terrace soils due to historical cultivation in the 
Budina cadastral area, Slovakia, Moravian Geographical Reports 23(2), 47-55. https://doi.org/10.1515/ mgr-2015-0010

SLÁMOVÁ, M. et al., 2017: Slámová, M.-Krčmářová, J.-Hronček, P.-Kaštierová, M., Environmental factors influencing the distribution of agricultural terraces: Case study of Horný Tisovník, Slovakia, Moravian Geographical Reports 25, č. 1, 34-45. https://doi.org/10.1515/mgr-2017-0004

STANKOVIANSKY, M., 2001: Tillage erosion and its geomorphic effect with special regard to the MyjavaWhite Carpathian kopanitse area, Geografický časopis 53, č. 2, 95-110.

- 2003: Historical and present slope evolution in hilly farmland (on the example of the Myjava Hill Land, Slovakia), Geografia Fisica e Dinamica Quaternaria 6, 91-97.

ŠPULEROVÁ, J. et al., 2009: Špulerová, J.-Štefunková, M.-Dobrovodská, M.-Babicová, D.-Bača, A.-Barančok, P.-Dávid, S.-Halabuk, A.-Halada, L.-Hrnčiarová, T.-Izakovičová, Z.-Kanka, R.-Kollár, J.Lieskovský, J.-Petrovič, F.-Ružičková, H.-Válkovcová, Z., Príručka na mapovanie historických štruktúr pol’nohospodárskej krajiny. Správa k projektu financovaného z EF: Výskum a zachovanie biodiverzity v historických štruktúrach pol’nohospodárskej krajiny Slovenska. Bratislava.

ŠPULEROVÁ, J.-PETROVIČ, F., 2011: Historical Agricultural Landscape as a Subject of Landscape Ecological Research, Hrvatski Geografski Glasnik 73(2), 155-163. https://doi.org/10.21861/HGG.2011.73.02.11

ŠPUlEROVÁ, J. et al., 2014: Špulerová, J., Dobrovodská, M., Štefunková, D., Piscová, V., Petrovič F., Evolution of the traditional agricultural landscapes of Slovakia. In: Environment and ecology in the Mediterranean region II (Efe, R.-Ozturk, M., edd.), 133-145. Newcastle.

ŠTATISTICKÝ ÚRAD SR, 2017: Datacube - Demografia a sociálne štatistiky; Regionálne štatistiky, pol'nohospodárstvo, lesníctvo a rybárstvo. Dostupné z: http://datacube.statistics.sk/TM1Web/TM1WebLogin.aspx, cit. 2. 3. 2017.

SWIECHOVICZ, J., 2002: The influence of plant cover and land use on the slope-channel decoupling in a foothill catchment: a case study from the Carpathian Foothills, Southern Poland. Earth Surface Processes and Landforms 27, 463-479.

TOMAŠTÍK, J. et al., 2017: Tomaštík, J.-Mokroš, M.-Saloň, Š.-Chudý, F.-Tunák, D., Accuracy of photogrammetric UAV-based point clouds under conditions of partially-open forest canopy, Forests 8(5), 151. https://doi.org/10.3390/f8050151

ÚRAD GEODÉZIE, KARTOGRAFIE A KATASTRA SLOVENSKEJ REPUBLIKY (ÚGKK SR), 2018: Portál Elektronických služieb katastra nehnutel'ností Slovenskej republiky (Portál ESKN). Dostupné z: https://kataster.skgeodesy.sk/eskn/services/NR/kn_wms_orto/MapServer/WmsServer?, cit. 4. 2. 2018.

VESELSKÁ, N., 2008: Využitie ústnych prameňov v historickom výskume, Forum Historiae 2, č. 1, $121-126$.

VOS, W.-MEEKES, H., 1999: Trends in European cultural landscape development: perspectives for a sustainable future, Landscape and Urban Planning, 46(1-3), 3-14. https://doi.org/10.1016/S0169-2046(99)00043-2

VÝSKUMNÝ ÚSTAV PÔDOZNALECTVA A OCHRANY PÔDY (VÚPOP), 2011: Pôdny portál - informačný servis VÚPOP, Bratislava, Typologicko-produkčné kategórie. Dostupné z: http://www.podnemapy.sk/portal/verejnost/tpk_pp/tpk.aspx, cit. 2. 3. 2017.

WORSTER, D., 1988: The Ends of the Earth: Perspectives on Modern Environmental History. Cambrige.

ZAPLETAL, L., 1968: Geneticko-morfologická klasifikace antropogénních forem reliéfu. SPN Praha, Acta universitatis Palackianae Olomucensis, Geographica - Geologia 23, 239-426.

- 1969: Úvod do antropogenní geomorfologie I. Skriptum. Olomouc.

\section{Zusammenfassung}

Die Umweltgeschichte der Gemeinde Horný Tisovník. Transformation der Bodennutzung ab dem späten Mittelalter über die neuzeitliche industrielle Expansion bis hin zur gegenwärtigen Aufgabe des ländlichen Gebietes

In den letzten Jahren begann die Umweltgeschichte damit, exakte Methoden dafür heranzuziehen, um Thesen über die ökologischen und umweltbedingten Beziehungen zwischen der Gesellschaft und den Landschaften der Vergangenheit nachzuweisen. Hauptziel des vorliegenden Beitrags war eine Interpretation der Umweltgeschichte der Landschaft seit den Anfängen der spätmittelalterlichen Besiedelung des Flusstals am Oberlauf des Baches Tisovník (derzeitiges Katastergebiet der Gemeinde Horný Tisovník) mit Schwerpunkt auf die Erläuterung der Ursachen für die Entstehung und Entwicklung von landwirtschaftlichen Terrassen und ihre geographische und räumliche Verbreitung in diesem Gebiet. Das betreffende Gebiet ist auf den ersten 
Blick wegen seines ausgedehnten Systems an landwirtschaftlichen Terrassen interessant, das die Hänge des Bachtals Tisovník bedeckt, obwohl es zu den landwirtschaftlich unvorteilhaften Gebieten zählt. Trotz einer urzeitlichen Besiedelung blieb der ursprüngliche Urwald bis zur Mitte des 16. Jahrhunderts fast ohne menschliche Eingriffe. Für diese Zeit ist der Beginn der Besiedelung im Tisovník-Tal schriftlich belegt und man vermutet auch die Entstehung der Terrassen, die in dem Katastergebiet in Richtung des geoklimatischen Gradienten chronologisch nacheinander von Süden nach Norden angelegt wurden. Die am Lauf des Baches Tisovník entlang verlaufenden Grenzen der Burgherrschaften haben sich in der zweiten Häfte des 13. Jahrhunderts in einem Waldgebiet herausgebildet, als der westliche Teil der Herrschaft zu Burg Modrý Kameň und der östliche Teil der Herrschaft zu Burg Divín gehörte und gerade ihre Burgverwaltungen und die jeweils unterschiedliche wirtschaftliche Orientierung in den darauffolgenden Jahrhunderten eine unterschiedliche Entwicklung der Landschaftsnutzung bewirkte. Im von Burg Modrý Kameň beherrschten Teil dominierte die Landwirtschaftsproduktion, was positiv mit der hohen Terrassendichte korrelierte, und im von Burg Divín beherrschten Teil überwogen gewerbliche und handwerkliche Produktionstätigkeiten, Terrassen gab es dort statistisch bedeutend weniger. $\mathrm{Ab}$ der Neuzeit setzte sich bei der Transformation der Landschaft zunehmend die Holzfällerei, Köhlerei und Glashüttenindustrie durch. Diese Aktivitäten bewirkten einen deutlichen Schwund der Wälder und gleichzeitig wahrscheinlich auch eine Zunahme der Anzahl an Terrassen. Eine vielfältige und wachsende industrielle Tätigkeit bewirkte eine Intensivierung der landwirtschaftlichen Tätigkeit in diesem Gebiet, die an der Wende des 19.-20. Jahrhunderts und zu Beginn des 20. Jahrhunderts ihren Höhepunkt fand. Im Gelände verifizierten wir das Vorkommen unterschiedlicher Terrassentypen sowie ihre Grundparameter. In dem untersuchten Gebiet haben wir von selbst entstandene Terrassen identifiziert, die bei einer schichtmäßigen Feldbestellung spontan entstanden, und an einigen Hängen wurden die Terrassen mit Trockenmauern angelegt. Manchmal wurden im Terrassenkörper absichtlich Bäume gepflanzt. In der Vergangenheit hat man die Terrassen auf sehr kleinen, wenigen Hektar großen Grundstücken bewirtschaftet, wie wir es am Beispiel einer Modellfundstätte belegen. Es entstanden, bzw. es wurden niedrige (bis zu 0,5 m), mittelhohe sowie hohe (über 1,5 m) Terrassen angelegt. Vergleicht man die gegenwärtige Nutzung des Bodens mit der Situation, die man auf der Karte der ersten militärischen Kartierung vorfindet (1764-1787), können wir festhalten, dass sowohl in der Vergangenheit, als auch in der Gegenwart in der Vegetationseinheit der Karpatischen Eichen-Hagebuchenwälder eine landwirtschaftliche Nutzung des Bodens überwog (62\%) und dass auf landwirtschaftlich genutztem Boden auch die größte Terrassendichte herrschte $\left(9,7 \mathrm{~km} / \mathrm{km}^{2}\right)$. Flächenmäßig am größten ist die Einheit der Vorgebirgsbuchenwälder $\left(20,1 \mathrm{~km}^{2}\right)$. Gemäß der historischen Karte der zweiten militärischen Kartierung (1810-1869) kamen Wälder in dieser Vegetationseinheit nur stellenweise vor. Die landwirtschaftliche Nutzung nimmt gegenwärtig 34\% der Ausdehnung der Vegetationseinheit ein, und die Terrassen haben gegenüber der südlich gelegenen Einheit eine vergleichbare Dichte von $9,4 \mathrm{~km} / \mathrm{km}^{2}$. Buchen- und Tannen-Buchenwälder haben eine den Karpatischen Eichen-Hagebuchenwäldern vergleichbare Ausdehnung, jedoch nimmt der landwirtschaftlich genutzte Boden in der Einheit nur 38\% ein. Eine zur gegenwärtigen Form verdichtete Streusiedlung nachhaltigen Charakters entstand dort erst zur Wende des 19. und 20. Jahrhunderts, und die Terrassendichte beträgt dort $6,3 \mathrm{~km} / \mathrm{km}^{2}$. In dem landwirtschaftlich genutzten Gebiet wird die insgesamt größte Fläche von weniger produktivem Dauergrünland eingenommen (4,5 $\mathrm{km}^{2}$ ), dort befinden sich auch die meisten Terrassen $(52,5 \mathrm{~km})$. Am zweithäufigsten vertreten, sowohl hinsichtlich Ausdehnung, als auch in der Anzahl der Terrassen, ist wenig produktives Dauergrünland. Jedoch ist dort Potenzial für eine Feld-Gras-Wechselwirtschaft vorhanden, und zwar vor allem in der Einheit der Karpatischen Eichen-Hagebuchenwälder und in der Aue des Baches Tisovník. Aufgrund der natürlichen Gegebenheiten, der Archivangaben sowie der statistisch bedeutend höheren Terrassenkonzentration in der Herrschaft von Burg Modrý Kameň, die sich auf die Landwirtschaftsproduktion und den Anbau von Feldfrüchten konzentrierte, nehmen wir an, dass die Terrassen von der Bevölkerung hauptsächlich zur Gewinnung von Ackerland und erst sekundär zu ihrer alleinigen Nutzung als Grünland angelegt wurden. Die Terrassen 
regulieren die Neigungsverhältnisse des landwirtschaftlichen Bodens positiv und verbessern auch noch weitere Produktionseigenschaften. Jedoch verzeichnen mehrere Archivmaterialien eine schlechte Bodenqualität und belegen auch historische Erosionsvorkommnisse. Wir können festhalten, dass dort Potenzial für Ackerboden, bzw. für Feld-Gras-Wechselwirtschaft vorhanden ist und von den Terrassen sogar verbessert wurde, dies andererseits in der Gegenwart jedoch nicht mehr genutzt wird. Aus einem Vergleich zwischen dem Terrassenvorkommen in den Wäldern $\left(86,1 \mathrm{~km}\right.$ auf einer Fläche von $\left.18,1 \mathrm{~km}^{2}\right)$ und in der Agrarlandschaft $(109,5 \mathrm{~km}$ auf einer Fläche von 12,3 $\mathrm{km}^{2}$ ) ergibt sich, dass die Agrarlandschaft infolge der abnehmenden landwirtschaftlichen Tätigkeit zu Wald wird. Die Terrassen sollten nicht nur als kulturelles und historisches Erbe im Landschaftsbild erhalten bleiben, sondern auch deshalb, um auch weiterhin die wichtige Funktion als Erosionsschutz zu erfüllen. Deshalb empfehlen wir die aktive Nutzung einer größtmöglichen Anzahl an Terrassen, deren Holzbestand noch nicht über 50\% liegt, und zwar sowohl in der Umgebung der Gemeinden Dolný und Horný Tisovník, wo die Terrassen als Ackerboden, bzw. in Form einer Feld-Gras-Wechselwirtschaft genutzt werden können, als auch in unmittelbarer Umgebung der Einsiedeleien im nördlichen Teil des Gebietes.

Die vorliegende Arbeit wurde von der Wissenschaftlichen Förderagentur des Ministeriums für Schulwesen, Wissenschaft, Forschung und Sport der Slowakischen Republik und der Slowakischen Akademie der Wissenschaften (VEGA Nr. 1/0868/18) gefördert.

Das Projekt ERASMUS+ Nr. 2016-1-SK01-KA202-022502, "FEAL: multifunctional Farming for the sustainability of European Agricultural Landscapes" wurde finanziell von der Europäischen Kommission gefördert. Die vorliegende Publikation gibt ausschließlich die Meinung des Verfassers wieder und die Kommission haftet für keinerlei in der vorliegenden Publikation enthaltenen und verwendeten Informationen.

Ing. Martina Slámová, PhD., Katedra plánovania a tvorby krajiny Fakulty ekológie a environmentalistiky Technickej univerzity vo Zvolene, T. G. Masaryka 24, SK 96053 Zvolen, Slovenská republika, martina.slamova@tuzvo.sk

PaedDr. Pavel Hronček, PhD., Ústav zemských zdrojov Oddelenia geo a montánneho turizmu Fakulty baníctva, ekológie, riadenia a geotechnológií Technickej univerzity v Košiciach, Letná 9, SK 04200 Košice, Slovenská republika,phroncek@gmail.com 